\title{
EDUCAÇÃO AMBIENTAL E EXTRAÇÃO CLANDESTINA DE PALMITO JUÇARA (Euterpe edulis): O CASO DO PARQUE ESTADUAL "CARLOS BOTELHO" - SÃO PAULO
}

\section{MARIA CLAUDIA NOGUEIRA}

\author{
Dissertação apresentada à Escola Superior de \\ Agricultura "Luiz de Queiroz", Universidade de \\ São Paulo, para obtenção do título de Mestre em \\ Recursos Florestais, com opção em Conservação \\ de Ecossistemas Florestais.
}

$P I R A C I C A B A$

Estado de São Paulo - Brasil

Agosto - 2003 


\section{EDUCACÃO AMBIENTAL E EXTRAÇÃO CLANDESTINA DE PALMITO JUÇARA (Euterpe edulis): O CASO DO PARQUE ESTADAL "CALOS BOTELHO" - SÃO PAULO}

\section{MARIA CLAUDIA NOGUEIRA}

Pedagoga

Orientador: Prof. Dr. MARCOS SORRENTINO

Dissertação apresentada à Escola Superior de Agricultura "Luiz de Queiroz", Universidade de São Paulo, para obtenção do título de Mestre em Recursos Florestais, com opção em Conservação de Ecossistemas Florestais.

PIR A C I C A B A

Estado de São Paulo - Brasil

Agosto - 2003 
Dados Internacionais de Catalogação na Publicação (CIP) DIVISÃO DE BIBLIOTECA E DOCUMENTAÇÃO - ESALQ/USP

Nogueira, Maria Claudia

Educação ambiental e extração clandestina de palmito Juçara (Eutepe edulis) : o caso do Parque Estadual "Carlos Botelho" - São Paulo / Maria Claudia Nogueira. - - Piracicaba, 2003.

$75 \mathrm{p}$.

Dissertação (mestrado) - - Escola Superior de Agricultura Luiz de Queiroz, 2003.

Bibliografia.

1. Área de conservação - Uso 2. Educação ambiental 3. Palmito - Extraçã 4. Parque Estadual "Carlos Botelho, SP 5. Visitante I. Título

CDD 333.72

"Permitida a cópia total ou parcial deste documento, desde que citada a fonte - O autor" 
Aos que acreditam que a potencialidade humana pode garantir a vida em suas

diferentes formas...

Ao Cristo de Nazaré, que me incentivou a ser e estar com os meus pares...

A minha estimada família, que me incentivou a falar...

À amiga Dirce Rodrigues (in memorian) e ao professor José Júlio Nunes Ferreira, que me incentivaram a ler...

Aos professores Marcos Sorrentino e Carlos Rodrigues Brandão, que me incentivaram a ouvir...

Aos professores Renato da Silva Queiroz e Oriowaldo Queda, que me incentivaram a escrever...

Dedico. 


\section{AGRADECIMENTOS}

À Coordenação de Aperfeiçoamento de Pessoal de Nível Superior (CAPES), cujo apoio financeiro possibilitou a execução deste trabalho.

Ao professor Dr. Marcos Sorrentino e à equipe do Laboratório de Educação e Política Ambiental (Oca) da ESALQ/USP pelo ensino de um modo específico de se fazer educação ambiental.

À coordenação do Programa de Pós-Graduação em Recursos Florestais da USP e funcionários do Departamento de Ciências Florestais da ESALQ pela eficiência na condução do curso de pós-graduação.

Aos funcionários do Restaurante Universitário e da Biblioteca Central da ESALQ/USP pela atenção durante os anos de convivência.

À Assistência Social, que disponibilizou uma vaga na Vila de moradores da Pós-graduação.

Às docentes que participaram da banca do exame de qualificação: Dra. Teresa Cristina Magro, Dra. Eneida Costa e Dra. Maria Elisa Garavello.

Ao Sr. José L. C. Maia, aos monitores da AMASMA (Associação de Monitores Ambientais de São Miguel Arcanjo) e funcionários do PE "Carlos Botelho", cujo apoio profissional viabilizou o primeiro contato com o tema deste trabalho.

Aos que, no município de São Miguel Arcanjo, Itapetininga e Registro, colaboraram na coleta dos dados. 
Ao Dr. Gil de Menezes e ao Eduardo Logunwa Erin Epega, que cuidaram do meu bem-estar físico e emocional.

Ao Fábio, Wirifran, Viviane, Winter, Mário, Cláudia, Raquel, Marcos, Ana Clara, Marisônia, Nora, Ana Paula, Felino (in memorian), Cláudia e Daniela cuja amizade garantiu, entre outras coisas, a satisfação de cursar essa pósgraduação.

Aos meus amigos e a minhas amigas de São Miguel Arcanjo, que sempre compreenderam as minhas escolhas e caminhos.

Às educadoras ambientais Beatriz Vasaki, Eliana Souto e Lígia Pupato, cujo incentivo favoreceu a minha escolha profissional no campo da educação ambiental em áreas naturais protegidas.

Ao professor Dr. Levino Bertan, professora Dra.Teresa Bertan (in memoriam) e professora Leda Lovato (in memorian), cuja dedicação proporcionou o início de meus trabalhos no campo da ciência, uma das tantas formas de trabalhar e perceber o mundo. 


\section{SUMÁRIO}

Página

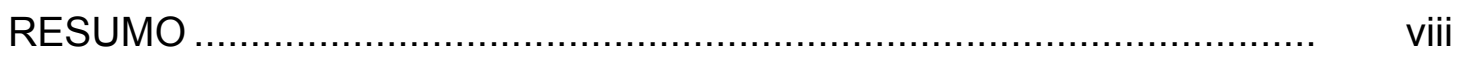

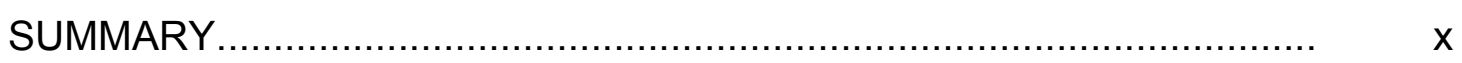

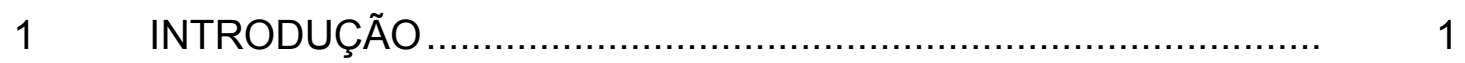

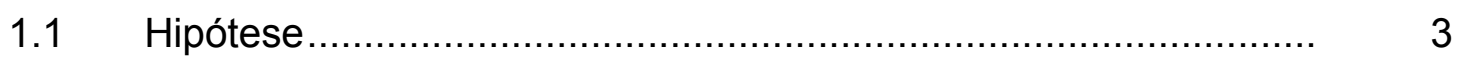

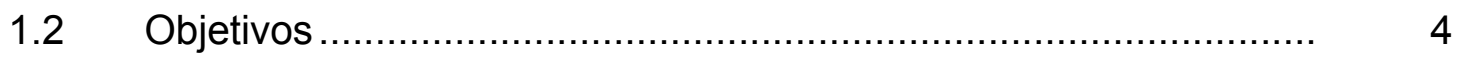

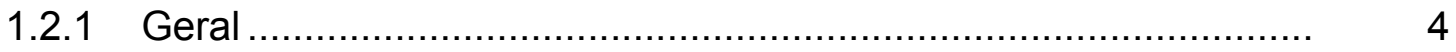

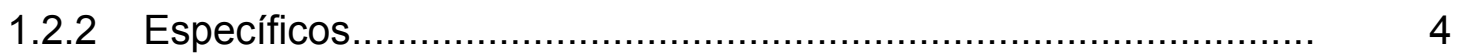

2 REVISÃO DE LITERATURA ...................................................... 5

2.1 Os modelos como construção do que se deseja conhecer............. 5

2.2 Política educacional e correntes pedagógicas no Brasil .................. 6

2.2.1 Correntes de cunho liberal ....................................................... 6

2.2.2 Correntes de cunho progressista ..............................................

2.3 Educação ambiental no contexto do movimento ambientalista e suas principais correntes

2.4 Programa de Uso Público do Instituto Florestal: um modo de pensar e fazer educação ambiental 
2.5 Programa de Uso Público do Parque Estadual "Carlos Botelho": educação ambiental e lazer

3 METODOLOGIA

3.1 Pesquisa qualitativa

3.2 Estudo de caso

3.3 Procedimentos ............................................................. 24

Coleta de dados............................................................ 25

3.5 Análise e interpretação dos dados .............................................. 27

3.6 Cenário de estudo................................................................. 27

3.7 Sujeitos da pesquisa ......................................................... 29

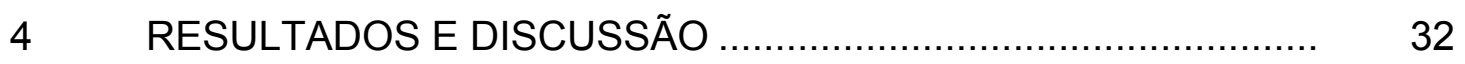

4.1 Políticas de gestão no Parque Estadual "Carlos Botelho"............. 32

4.2 Extrativismo nas unidades de conservação de proteção integral do Alto Vale do Ribeira

4.3 A necessidade de partilhar estratégias de conservação com a população do entorno

5 CONCLUSÃO

REFERÊNCIAS BIBLIOGRÁFICAS .............................................. 52

APENDICES 


\title{
EDUCAÇÃO AMBIENTAL E EXTRAÇÃO CLANDESTINA DE PALMITO JUÇARA (Euterpe edulis): O CASO DO PARQUE ESTADUAL "CARLOS BOTELHO"' SÃO PAULO
}

\author{
Autora: MARIA CLAUDIA NOGUEIRA \\ Orientador: Prof. Dr. MARCOS SORRENTINO
}

\section{RESUMO}

Neste trabalho investigou-se planos e ações de educação ambiental do Parque Estadual "Carlos Botelho" (PECB) buscando possíveis relações com os distúrbios antrópicos em seu interior causados pela extração clandestina de palmito (Euterpe edulis). Esta área é considerada uma Unidade de Conservação de Proteção Integral e abrange 37.644,36 ha localizados na região sul do Estado de São Paulo. Sua porção que pertence ao Vale do Ribeira, em conjunto com outras unidades de conservação (Parque Estadual Turístico do Alto Ribeira e Parque Estadual Intervales), compõem um importante continuum ecológico do estado de São Paulo. Entre 1988 a 1994, apesar do poder público não destinar recursos institucionais para a formalização de atividades educacionais no PECB, iniciam-se as atividades de educação ambiental nessa área com o apoio financeiro do World Wildlife Fund (WWF) e da Fundação O Boticário de Proteção à Natureza. A partir da coleta e analise dos processos técnico-administrativos, dos relatórios de projetos e das atas de reunião do Parque, referentes ao período de 1988 a 2000, obteve-se os 
elementos necessários para compreender o histórico do Programa e sua fundamentação pedagógica. A metodologia adotada foi a de estudo de caso. Foram compilados também dados secundários sobre a extração de palmito na polícia ambiental e delegacia da região e realizadas entrevistas com indivíduos que, de algum modo, estão ligados à rede de extração de palmito e à população do entorno. Foi elaborado um diário de campo, com registros fotográficos e registros de reuniões entre setembro de 1999 a novembro de 2000 , onde se registrou as atividades do Programa de Educação Ambiental e Uso Público do Parque. Neste contexto, procurou-se identificar a forma com que os distúrbios antrópicos, mais especificamente a extração clandestina de palmito, são trabalhados na gestão do Parque e mais especificamente no Programa de Uso Público, no subprograma de educação ambiental. Constata-se a carência de um tratamento mais aprofundado do conflito como estratégia privilegiada para se fazer educação ambiental. 


\section{ENVIRONMENTAL EDUCATION AND CLANDESTINE EXTRACTION OF THE HEART OF PALM Euterpe edulis: THE CASE "CARLOS BOTELHO" STATE PARK}

Author: MARIA CLÁUDIA NOGUEIRA

Adviser: Prof. Dr. MARCOS SORRENTINO

\section{SUMMARY}

The main objective of this work was to investigate plans and actions of environmental education developed by "Carlos Botelho" State Park (CBSP) related to riots caused by the clandestine extraction of the heart of palm Euterpe edulis. This area $(37,644.36 \mathrm{ha})$ is located in the south of the state of São Paulo and it is considering Integral Unit of Conservation and Protection. The Ribeira Valley, which composes an important ecological continuum area, is formed by other two units of conservation (Alto do Ribeira Tourist State Park and Intervales State Park). From 1988 to 1994 the brazilian government did not give any support to promote environmental educational activities at CBSP, but it was possible to start the environmental education program, which was supported by the following no governmental organizations: World Wildlife Fund (WWF) and Boticário Foundation to Nature Protection. Based on the collected and analyzed administrative technical processes, project reports and acts of meeting occurred at CBSP during the period of 1988 to 2000, it was possible to obtain the necessary elements to understand the environmental program historic and how it was base on. The methodology adopted was the case study. It was compiled a secondary data about the heart of palm extraction, which were given by the 
policy and people from the neighborhood of the park and individuals who had been in contact with the environmental program or other activities developed by the park as well as the extraction of the heart of palm Euterpe edulis were interviewed. From September 1999 to November 2000 a field daily was elaborated and photos, meetings and activities of the environmental education program and public use developed by the park were registered. In this context and considering the environmental education subprogram, it was identified how the riots, specifically the clandestine extraction of the heart of palm Euterpe edulis, has been incorporated in the management of the park. It was found that the clandestine extraction of the heart of palm Euterpe edulis is not treated as it should be to guarantee the environmental education program efficiency. 


\section{INTRODUÇÃO}

No Estado de São Paulo, quase a totalidade das áreas naturais legalmente protegidas, está sob os cuidados da Secretaria Estadual do Meio Ambiente. Áreas protegidas são áreas de terras e/ou mar especificamente dedicadas à proteção e manutenção da diversidade biológica, e de seus recursos naturais e culturais associados, manejadas por instrumentos legais, segundo o Sistema Nacional de Unidades de Conservação (2003).

No âmbito da SMA, o Instituto Florestal é o responsável pela proteção e gestão da maior parte das áreas naturais protegidas, que são chamadas Unidades de Conservação (UC's). Adotando a mesma definição do Sistema Nacional de Unidades de Conservação SNUC (2003), o Instituto Florestal administra 80 dessas unidades de conservação, que, somadas, abrangem uma área de 851.547,94, aproximadamente 3\% da área do Estado (Brito, 2000).

No Brasil, como em quase todo o mundo, as unidades de conservação têm finalidades educativas como uma de suas atribuições. Sob a responsabilidade principalmente de órgãos governamentais, esse tipo de trabalho constitui importante alternativa de educação não-formal. As atividades de educação ambiental constituem-se como uma das estratégias adotadas para a busca de apoio comunitário para a proteção e valorização das unidades, segundo Simões ${ }^{1}$, citado por Tabanez (2000).

Ensinar a ler, escrever, ouvir e a falar, para Gadotti (1985), é função da escola, trata-se da denominada educação formal. Ações e práticas coletivas organizadas são funções dos movimentos, entidades e associações sociais e

\footnotetext{
${ }^{1}$ SIMÕES, E. Uma educação ambiental possível: a natureza do Programa da llha. São Paulo: PUC, 1998. 187 p. Dissertação (Mestrado) - Faculdade de Educação.
} 
são chamadas de educação não-formal. As práticas cotidianas desempenhadas nos espaços de possibilidades educativas junto aos pais, na família, no convívio com os amigos, em clubes, em teatros, na leitura de jornais, livros, revistas etc. são consideradas temas da educação informal, segundo Gonh (1999).

"Uma das justificativas para a criação de Unidades de Conservação cuja categoria prevê a visitação e o uso público é possibilitar o acesso das pessoas às áreas naturais. Acredita-se que o contato com a natureza traga muitos benefícios aos indivíduos e que as áreas protegidas podem desempenhar um importante papel de formadoras de consciência ambiental, quando o indivíduo estabelece uma relação participativa com elas". (Barros, 2003, p. 5)

Segundo Vasconcellos (2002), a educação ambiental faz parte de todas as categorias de manejo das unidades de conservação brasileiras. Isso significa que as áreas naturais protegidas como unidades de conservação (UC) devem ser planejadas e manejadas para que, de alguma forma, consigam envolver as pessoas, estimulando mudanças de comportamento. Citando Carvalho ${ }^{2}$, apresenta o pressuposto de que a educação ambiental pode ser compreendida como um ato responsável de cidadania, de solidariedade e de compromisso com os valores ecológicos.

Para tanto, esta autora adverte que não existem receitas ou fórmulas prontas. Mesmo importantes experiências de outros países não devem ser simplesmente adotadas e reproduzidas. As diferentes realidades brasileiras exigem a construção de práticas particularizadas, as quais passam pela avaliação e divulgação dos caminhos que estão sendo tentados, pela troca de experiências, pela recriação e readaptação de métodos.

De acordo com Andrade et.al. (1992), a categoria "Parque Estadual" foi definida como uma área de porte considerável (geralmente com mais de 1000

\footnotetext{
${ }^{2}$ CARVALHO, I.C. de M. Em direção ao mundo da vida: interdisciplinariedade e educação ambiental. Brasília: IPE Instituto de Pesquisas Ecológicas, 1998. 101 p.
} 
ha), susceptível de manejo em estado natural ou quase natural, contendo formações ou paisagens de características naturais relevantes; onde espécies de plantas, de animais, sítios geomorfológicos e habitats são de grande interesse científico, educacional ou recreacional.

Tabanez (2000), ao definir o papel das unidades de conservação, como sendo a via mais efetiva de proteção dos processos ecológicos, afirma que a criação, apenas, dessas unidades não basta, para assegurar a proteção dos recursos naturais, culturais e históricos. Uma evidência desse alerta é o fato de que, no Brasil, a criação, por força da lei, de parques, estações experimentais ou ecológicas e outras áreas naturais protegidas que podem ser abrangidas sob o nome de "unidades de conservação", não têm conseguido impedir todo o tipo de pressão por parte das comunidades circunvizinhas.

Num artigo publicado por Vasaki et al. (1992), constata-se que um dos objetivos do Programa de Uso Público do Parque Estadual "Carlos Botelho", é a tentativa de conter da invasão no Parque, via educação ambiental. Esse objetivo, possivelmente, está ligado ao fato de que, apesar dos atributos que fazem com que o Parque tenha o título de patrimônio natural da humanidade, ele é cenário da ação de grupos organizados para a retirada de palmito.

Este trabalho, tendo como objeto de estudo o Programa de Uso Público do Parque Estadual "Carlos Botelho", abordou a questão específica da educação ambiental como uma estratégia de manejo. Acredita-se que a ação clandestina de extração de palmito, que é fonte geradora de conflitos, deve ser enfrentada com projetos educacionais, econômicos e sociais que levem em consideração o contexto local, bem como os princípios da educação ambiental.

\subsection{Hipótese}

O subprograma de educação ambiental, do Parque Estadual "Carlos Botelho" não problematiza e nem propõe alternativas para questões conflituosas como a extração clandestina de palmito e os planos e ações 
específicos de educação ambiental, se mostram ineficientes e ineficazes para diminuir os níveis de perturbação antrópica no interior do Parque.

\subsection{Objetivos}

\subsubsection{Geral}

Contribuir com a produção de conhecimentos na área de Educação Ambiental em unidades de conservação de modo a fortalecer as ações do Programa de Uso Público, subprograma de educação ambiental referentes à proteção da diversidade cultural e biológica.

\subsubsection{Específicos}

i) Investigar os planos do Parque Estadual "Carlos Botelho", em relação aos distúrbios antrópicos, especificamente relacionados à extração clandestina de palmito juçara (Euterpe edulis);

ii) apresentar sugestões e propostas para o subprograma de educação ambiental, enfatizando aquelas que contribuam para fazer do conflito no interior do Parque, um potencializador da educação. 


\section{REVISÃO DE LITERATURA}

\subsection{Os modelos como construção do que se deseja conhecer}

Segundo Alves (1985), não importam as diferenças que separam o senso comum da ciência: ambas estão em busca de ordem. A exigência de ordem se fundamenta na própria necessidade de sobrevivência. Não existe vida sem ordem nem comportamento inteligente sem ela, mas não se pode negar, por outro lado, que o senso comum e a ciência apresentam visões de ordem muito diferentes uma da outra.

A ciência se inicia com problemas. Um problema significa que há algo errado ou não resolvido com os fatos. O seu objetivo é descobrir uma ordem invisível que transforme os fatos de enigma em conhecimento. A investigação científica não termina com os seus dados; ela se inicia com eles. O produto final da ciência é uma teoria ou hipótese de trabalho e não, os assim chamados, fatos.

A essas construções da imaginação se dá, comumente, o nome de modelos. Os modelos são construções intelectuais, palpites, apostas baseadas na crença de que existe uma relação de analogia entre aquilo que se conhece e o que se deseja conhecer.

"Muito do nosso conhecimento tem o caráter de ferramenta. E o conhecimento que tem o caráter de ferramenta pode ser denominado receita. Uma receita é uma série de instruções sobre coisas a serem feitas, se se deseja obter um resultado determinado" (Alves, 1985, p.48). Essa discussão 
leva a uma aproximação da tese de Thomas $\mathrm{Kuhn}^{3}$, o qual descreve que não há métodos para construção de teorias mas, antes, com aquilo a que ele dá o nome de paradigmas, que são visões de mundo mais abrangentes que teorias.

Para Alves (1985), uma vez constituído um paradigma, instaura-se o que Kuhn denomina "ciência normal", que são as pesquisas baseadas firmemente em uma ou mais conquistas passadas da ciência, conquistas que uma certa comunidade científica particular reconhece, por um certo período de tempo, como oferecendo as bases para sua prática posterior.

Para Marcondes (1994), uma crise de paradigmas caracteriza-se, assim como uma mudança conceitual, ou uma mudança de visão de mundo, como conseqüência de uma insatisfação com os modelos anteriormente predominantes de explicação. A crise de paradigmas leva geralmente a uma mudança de paradigmas, sendo que as mudanças mais radicais consistem em revoluções científicas.

\subsection{Política educacional e correntes pedagógicas no Brasil}

\subsubsection{Correntes de cunho liberal}

Nos anos 30, no Brasil, segundo Ghiraldelli (2001), era possível identificar quatro projetos distintos para a construção de um "novo Brasil" e, conseqüentemente, quatro diferentes pensamentos sobre a educação brasileira. Liberais, católicos e integralistas, governistas e aliancistas coloriram o debate político e educacional dos anos 30.

Segundo este autor, por um lado, situaram-se os liberais-intelectuais que expressavam os desejos da construção de um país em bases urbano-industriais democráticas e que, no plano educacional, endossavam as teses gerais da Pedagogia Nova. Foram esses que encetaram a maioria das reformas educacionais estaduais dos anos 20, e que, por isso, passaram a ser conhecidos como profissionais da educação.

\footnotetext{
${ }^{3}$ KUHN, T.S. A estrutura das revoluções científicas. 2. ed. São Paulo: Perspectiva, 1987.
} 
As críticas à pedagogia tradicional formuladas a partir do final do século XIX foram, aos poucos, dando origem a uma outra teoria da educação. Se a escola não vinha cumprindo essa função, isso se devia ao fato de que o tipo de escola implantado - a escola tradicional- se revelava inadequado, afirmou Saviani (1992). A pedagogia nova começa, pois, por efetuar a crítica da pedagogia tradicional, esboçando uma nova maneira de interpretar a educação e ensaiando implantá-la; primeiro, através de experiências restritas; depois, advogando sua generalização no âmbito dos sistemas escolares.

Em oposição direta aos liberais, situaram-se os católicos. Defensores da Pedagogia Tradicional ${ }^{4}$, os católicos reagiram ao "Manifesto", orquestrando uma bateria poderosa contra as teses escolanovistas. No centro dessa disputa ficou o governo, que procurou aparentar situar-se numa posição de neutralidade. Uma quarta força, social se expressou através da Aliança Nacional Libertadora (ANL), entidade que aglutinou boa parcela das classes populares - proletariado.

\section{ESCOLANOVISMO PIAGETIANO}

Para Ghiraldelli (1994) entre o final dos anos 50 e meados dos anos 80, cresceu de maneira significativa o número de textos e publicações na área da educação inspirados no piagetianismo ${ }^{5}$.

O trabalho realizado por Piaget $^{6}$ citado por Costa (1984) concentra-se principalmente na investigação teórica e experimental do desenvolvimento qualitativo das estruturas intelectuais, tendo como elemento principal a gênese do conhecimento. O desenvolvimento, no sistema de Piaget, apresenta uma abordagem evolutiva com uma dimensão genética.

\footnotetext{
${ }^{4}$ Para Libâneo (1994), na pedagogia tradicional, a atividade de ensinar é centrada no professor que expõe e interpreta a matéria. Às vezes são utilizados meios como a apresentação de objetos, ilustrações, exemplos, mas o meio principal é a palavra, a exposição oral.

${ }^{5}$ A teoria psicológica de Jean Piaget, que colocou nas mãos do professorado uma determinada interpretação do desenvolvimento da criança em fases cronológicas, ganhou uma razoável divulgação e praticamente conferiu um novo status de cientificidade às pesquisas pedagógicas e didáticas e mesmo à profissão de educador.

${ }^{6}$ Segundo Costa $(1984$, p.23) as primeiras preocupações de Piaget quanto ao desenvolvimento infantil forma de natureza epistemológica. Seus trabalhos raramente trazem uma referência bibliográfica, numa tendência a apresentar-se desvinculados das pesquisas e teorias afins.
} 
Envolve a descrição cuidadosa de mudanças comportamentais, de um funcionamento menos avançado para um mais avançado, dentro de um mesmo estágio ou entre estágios sucessivos, de modo que características dominantes de um estágio são descritas em função dos estágios precedentes e subseqüentes.

O desenvolvimento cognitivo é um processo crescente de adaptação ao meio, que se torna possível pelo equilíbrio gradativamente atingido. Esse processo tende à organização progressiva das estruturas internas em contato com o meio exterior. Tendendo a uma adaptação cada vez mais equilibrada ao meio, o organismo individual desenvolve-se através de sucessivos desequilíbrios e reequilíbrios entre os fatores internos e externos.

\section{PEDAGOGIA TECNICISTA}

Para Libâneo (1994), à medida que a década de 70 foi transcorrendo, a Pedagogia Tecnicista ${ }^{7}$ se delineou com características bastante próprias e, inclusive, passou a ser adotada como pedagogia oficial, compondo a maior parte das bibliografias dos concursos públicos para o ingresso na carreira do magistério. Invocando os princípios de racionalidade, eficiência e produtividade, concomitantemente, embasado na ótica do "enfoque sistêmico", o tecnicismo pedagógico buscou provar a sua superioridade científica sobre as teorias pedagógicas concorrentes.

De acordo com Saviani (1992), a partir do pressuposto da neutralidade científica e inspirada nos princípios de racionalidade, eficiência e produtividade, essa pedagogia advoga a reordenação do processo educativo de maneira a torná-lo objetivo e operacional. De modo semelhante ao que ocorreu no trabalho fabril, pretende-se a objetivação do trabalho pedagógico. Na pedagogia tecnicista, a marginalidade não será identificada com a ignorância nem será

\footnotetext{
${ }^{7}$ Ao findar a primeira metade do século, segundo Saviani (1992), o escolanovismo apresentava sinais visíveis de exaustão. As esperanças depositadas na reforma da escola resultaram em frustrações. Articula-se, a partir de então, uma nova teoria educacional: a pedagogia tecnicista.
} 
detectada a partir do sentimento de rejeição. Marginalizado será o incompetente, isto é, o ineficiente e improdutivo. Desse modo, a educação estará contribuindo para o aumento da produtividade da sociedade.

\subsubsection{Correntes de cunho progressista}

\section{PEDAGOGIA LIBERTÁRIA}

A pedagogia libertária, ao contrário das anteriores, não teve origem nas classes dominantes, afirma Ghiraldelli (2001). Vinculou-se aos intelectuais ligados aos projetos dos movimentos sociais populares, principalmente aos desejos de transformação social contidos nas propostas do movimento operário de linha anarquista ou anarco-sindicalista.

Essa pedagogia, para o autor, esteve associada às primeiras organizações do proletariado no Brasil e chegou no país pelas mãos dos trabalhadores imigrantes - italianos, espanhóis, portugueses, franceses etc. Esses chegaram ao Brasil para dar continuidade ao trabalho na lavoura do café e, posteriormente, deram origem ao proletariado urbano nas grandes cidades no início do século. Nos anos 70, vinculada a essa tendência, o não-diretivismo foi amplamente divulgado, chegando mesmo a ganhar status junto ao professorado como uma pedagogia de oposição ao regime, fazendo frente ao tecnicismo pedagógico, então tomado como pedagogia oficial.

\section{PEDAGOGIA LIBERTADORA}

No raiar do anos $60^{8}$, segundo Ghiraldelli (2001), o Brasil deixou efetivamente de ser um país "predominantemente agrícola". A população urbana começou a ultrapassar a população rural em número. O país passou a contar com um parque industrial diferenciado e muito produtivo.

\footnotetext{
${ }^{8}$ Para Ghiraldelli (2001), a movimentação dos anos 60 em torno da promoção da cultura popular prendeu-se às preocupações dos intelectuais jovens e alguns políticos com a emergência das massas na participação política do país. Liberais progressistas, esquerdas marxistas, social-democratas, esquerdas cristãs etc., empolgaram essas várias entidades que, imbuídas de nacionalismo, procuravam resgatar a cultura do povo como uma "verdadeira cultura não-dominante".
} 
Em meio à efervescência dos primeiros quatro anos da década de 60, cresceram organizações que trabalharam com a promoção da cultura popular, a educação popular, a alfabetização e a conscientização da população sobre a realidade dos problemas nacionais.

Os Centros Populares de Cultura (CPCs), os Movimentos de Cultura Popular (MCPs) e o Movimento de Educação de Base (MEB) foram os grandes protagonistas das ações de várias tendências e grupos de esquerda preocupados com a problemática das classes trabalhadoras. No seio desses movimentos surgiu a Pedagogia Libertadora, cuja origem está diretamente associada ao método de alfabetização de adultos de Paulo Freire e aos seus primeiros escritos sobre educação.

Como a Pedagogia Tradicional e a Pedagogia Nova, que podem ter seus processos de ensino representados em cinco passos, também a Pedagogia Libertadora pode sintetizar seu processo pedagógico dessa forma, como mostra o Quadro 1.

\begin{tabular}{lll}
\hline \multicolumn{1}{c}{ Pedagogia Tradicional } & \multicolumn{1}{c}{$\begin{array}{c}\text { Pedagogia Nova } \\
\text { (Dewey) }\end{array}$} & \multicolumn{1}{c}{ Pedagogia Libertadora } \\
Preparação & \multicolumn{1}{c}{ (Freire) } \\
Apresentação & Atividade & Pesquisa \\
Associação & Problema & Temas geradores \\
Generalização & Dados do problema & Problematização \\
Aplicação & Hipótese & (diálogo) \\
& Experimentação & Conscientização \\
& & Ação social
\end{tabular}

Quadro 1- Passos que sintetizam as distintas Pedagogias

Fonte: Ghiraldelli (2001) 


\section{PEDAGOGIA CRÍTICO SOCIAL DOS CONTEÚDOS}

A concepção histórico-crítica, tem como marco de sua configuração, segundo Saviani (1995), o ano de 1979. Nesse ano, o problema de abordar dialeticamente a educação começou a ser discutido mais ampla e coletivamente. A um grupo formado por alunos de doutorado da PUC-SP, foi proposto o desafio de formular teoricamente o fenômeno educativo, de modo que este fosse uma superação da teoria crítico-reprodutivista.

Em 1983, Saviani elaborou o texto "Onze teses sobre educação e política", publicado no livro Escola e democracia ${ }^{9}$, onde procurou caracterizar mais precisamente as relações entre política e educação de modo a superar tanto o "politicismo pedagógico" que dissolve a educação na política, quanto o "pedagogismo político" que dissolve a política na educação. E assim foi emergindo e tomando forma essa nova proposta pedagógica.

Conforme Libâneo (1994), a escola pública cumpre a sua função social e política, assegurando a difusão dos conhecimentos sistematizados a todos, como condição para a efetiva participação do povo nas lutas sociais. Não considera suficiente colocar como conteúdo escolar a problemática social cotidiana.

A pedagogia crítico-social dos conteúdos ${ }^{10}$, atribui grande importância à didática, cujo objeto de estudo é o processo de ensino nas suas relações e ligações com a aprendizagem. As ações de ensinar e aprender formam uma unidade, mas cada uma tem a sua especificidade.

\footnotetext{
${ }^{9}$ SAVIANI, D. Escola e democracia: teorias da educação, curvatura da vara, onze teses sobre educação e política. Campinas: São Paulo: Autores Associados, 1999. 104 p.

10 A Pedagogia crítico-social dos conteúdos busca uma síntese superadora de traços significativos da pedagogia tradicional e da Escola Nova. Toma o partido dos interesses majoritários da sociedade, atribuindo à instrução e ao ensino o papel de proporcionar aos alunos o domínio de conteúdos científicos, de modo a irem formando uma consciência crítica face às realidades sociais e capacitando-se a assumir, no conjunto das lutas sociais, a sua condição de agentes ativos de transformação da sociedade e de si próprios. (Libâneo, 1994)
} 


\subsection{Educação ambiental no contexto do movimento ambientalista e suas principais correntes}

Layrargues (2002), parafraseando Gonçalvez ${ }^{11}$, alerta a respeito da necessidade de romper uma equivocada percepção, que, infelizmente, resiste ao longo do tempo: a idéia de que o pensamento e o movimento ambientalista se conjugam no singular. A interpretação monolítica do ambientalismo e da educação ambiental, como se ambos fossem coesos numa única possibilidade, representa uma diluição da perspectiva da sociedade como um lugar dos conflitos por excelência.

O ambientalismo, segundo esse autor, é um fenômeno que se conjuga no plural, porque ele engloba múltiplas visões sobre a crise ambiental; múltiplas interpretações sobre as causas das questões ambientais; múltiplas percepções do relacionamento humano com a natureza; múltiplos interesses pela preservação da natureza; múltiplas representações dos conceitos analíticos que preenchem cognitivamente tais fontes de interpretação, a exemplo de natureza, meio ambiente, problema ambiental, conflito socio-ambiental, entre outros.

A primeira classificação que ilustra a diversidade interna do(s) movimento(s) ambientalista(s), se refere à interpenetração do pensamento ambientalista como uma ideologia filosófica. Segundo Layrargues (2002), na origem do pensamento ambientalista, há um equivalente daquela mesma dicotomia entre as forças sustentabilistas versus forças desenvolvimentistas: o ecocentrismo versus o antropocentrismo.

Há uma segunda classificação que se refere, à interpretação do pensamento ambientalista como uma ideologia política, que evidentemente guarda relações com a tipologia anterior e refere-se à perspectiva de internalização da variável ecológica na lógica dos sistemas políticos-ideológicos vigentes ou latentes. São esses: o eco-capitalismo, o eco-socialismo, o ecoanarquismo e o eco-autoritarismo. 
Uma terceira classificação do pensamento ambientalista existente, segundo Leis ${ }^{16}$, citado por Layrargues (2002), diz respeito à evolução da ética ecológica, onde podem existir quatro possibilidades da ética ecológica manifestar-se: alfa; beta; gama e ômega.

Uma quarta classificação do pensamento existente, efetuada por Herculano ${ }^{17}$, citada por Layrargues (2002), destaca sete vertentes, de acordo com as percepções a respeito das causas e respectivas propostas de enfrentamento da crise ambiental: fundamentalistas, alternativos, neomaltusianos, zeristas, verdes ou ecologistas sociais, eco-tecnicistase marxistas.

Uma quinta classificação proposta por Soffiati ${ }^{18}$, também citado por Layrargues (2002), coloca as atitudes políticas frente à crise ambiental: exponencialismo, compatibilismo, preservacionismo, conservacionismo' ambientalismo e ecologismo.

Uma última classificação, que segundo Layrargues (2002) merece registro, embora seja um desdobramento do ambientalismo como ideologia filosófica (antropocentrismo e ecocentrismo), diz respeito às práticas da luta ambientalista. Ainda não presente em destaque na literatura como categoria de análise, é a que resulta do recente encontro de duas dimensões de sustentabilidade: a ecológica e a social; criada a partir da Conferência do Rio: ambientalismo e socio-ambientalismo.

Uma outra classificação existente, não exatamente do pensamento, mas do movimento ambientalista, diz respeito ao seu perfil segundo a lógica de internalização da variável ambiental nos diversos setores sociais, afirma Layrargues (2002). Para isso, o autor toma como referência o trabalho de

\footnotetext{
${ }^{11}$ GONÇALVES, C.W.P. Os (des) caminhos do meio ambiente. São Paulo: Contexto, 1989, 148 p.

${ }^{16}$ LEIS, H.R. Ética ecológica: análise conceitual e histórica de sua evolução. IN: VÁRIOS AUTORES. Reflexão cristã sobre o meio ambiente. São Paulo: Loyola, 1992, p. 51-76.

${ }^{17}$ HERCULANO, S. Do desenvolvimento (in) suportável à sociedade feliz. IN: GOLDENBERG, M. (Coord.) Ecologia, ciência e política. Rio de Janeiro: Revan: 1992, p. 9-48.

${ }^{18}$ SOFFIATI, A. O ecologismo como uma das tendências filosóficas da atualidade. 1993. Mimeo.
} 
Viola $^{18}$, que procura identificar o processo de expansão das idéias e práticas ambientalistas no Brasil.

Havia na fase fundacional (1971-1986) do ambientalismo brasileiro, intitulada de bissetorialismo, a existência de dois setores no movimento: as entidades ecológicas estrito senso e os organismos estatais de controle ambiental. A barulhenta militância agiu como uma caixa de ressonância em que, a partir da Constituição, inicia a segunda fase do movimento, a de consolidação do ambientalismo, intitulado de multissetorial, que assiste à incorporação de vários outros segmentos sociais.

A fase pós-Rio 92, quando o multissetorialismo começa a transmutar-se em transsetorialismo, em função do surgimento das redes temáticas que tecem laços de união entre os vários setores. E, finalmente, dez anos depois, na Rio+10, inicia-se a entrada de um outro setor, o Judiciário, que se faz presente no movimento ambientalista, num momento em que a institucionalização e o estabelecimento do marco legal da questão ambiental, já avançados, necessitam de balizas jurídicas para a devida mediação e responsabilização dos crimes e danos ambientais.

Segundo Layrargues (1992) da mesma forma que o ambientalismo, atualmente não é mais possível entender a educação ambiental no singular, como um único modelo alternativo de educação que simplesmente se opõe à educação convencional, que não é ambiental. Há novas denominações para conceituar Educação Ambiental cunhadas a partir do final da década de 80 e início da de 90. Entre essas: alfabetização ecológica, educação para o desenvolvimento sustentável, educação para a sustentabilidade, ecopedagogia e educação no processo de gestão ambiental.

A partir de elementos ainda não visíveis, que demarcassem táticas e estratégias de maior poder de eficácia para atingir resultados nem sempre

\footnotetext{
${ }^{18}$ VIOLA, E.J. O movimento ambientalista no Brasil (1971- 1991): da denúncia e conscientização pública para a institucionalização e o desenvolvimento sustentável. IN: GOLDENBERG, M. (Coord.) Ecologia, ciência e política. Rio de Janeiro: Revan, 1992, p.49-75.
} 
palpáveis, como é o caso do processo educativo, Sorrentino ${ }^{19}$, citado por Layrargues (2002), empreendeu a tarefa de identificar a existência de quatro vertentes: conservacionista, educação ao ar livre, gestão ambiental e economia ecológica.

Com base em Layrargues (2002), verifica-se que a educação ambiental é tão vasta quanto à diversidade que inspira as inúmeras variações do ambientalismo, Sauvé ${ }^{20}$, citado por Layrargues (2002), discute algumas delas, embora possam ser, ao contrário do ambientalismo, complementares entre si: educação sobre o meio ambiente, educação no meio ambiente e educação para o meio ambiente.

Layrargues (2002) apresenta ainda uma outra classificação, que diz respeito às perspectivas que iluminam as práticas pedagógicas, divididas entre um maior peso conferido à educação ou ao meio ambiente, embora também possam ser complementares entre si: perspectiva ambiental, perspectiva educativa e perspectiva pedagógica.

Por fim Carvalho ${ }^{21}$ citada por Layrargues (2002), salienta que foi a compreensão da educação ambiental, a partir de sua função social, que propiciou o surgimento de tipologias dualistas com categorias intrinsecamente binárias, internamente ao campo da educação ambiental. Inicialmente essa autora contrapôs uma educação ambiental alternativa contra a educação ambiental oficial.

Quintas $^{22}$, Guimarães ${ }^{23}$ e Lima ${ }^{24}$, citados por Layrargues (2002), respectivamente, defendem uma educação no processo de gestão ambiental,

\footnotetext{
${ }^{19}$ SORRENTINO, M. Educação Ambiental e universidade: um estudo de caso Tese (Doutorado) - São Paulo, 1995, 335 p. Faculdade de Educação Universidade de São Paulo.

${ }^{20}$ SAUVÉ, L. Pour une éducation relative à l'envoronnement. Montreal: Guérin. 2 éd. 1997, 86 p.

${ }^{21}$ CARVALHO, I.C.M. Territorialidades em luta: uma análise dos discursos ecológicos. Séries Registros, n. 9, pp.1-56, São Paulo: Instituto Florestal, Secretaria do Meio Ambiente,1991.

${ }^{22}$ QUINTAS, J.S. ; GUALDA, M.J.A. A formação do educador para no processo de gestão ambiental. Brasília: IBAMA, 1995. $123 \mathrm{p}$.

${ }^{23}$ GUIMARÃES, M. Educação ambiental: no consenso, um embate? . Campinas: Papirus, 2000, 96 p.
} 
uma educação ambiental crítica e uma educação ambiental emancipatória contra a educação ambiental convencional.

Ainda no que diz respeito à função social da Educação, Layrargues (2002) sublinha a existência de uma outra classificação, referente às correntes pedagógicas às quais todo e qualquer programa educativo, necessariamente, se circunscreve, inclusive a educação ambiental: Pedagogia Liberal e Pedagogia Progressista.

\subsection{Programa de Uso Público do Instituto Florestal: um modo de pensar e fazer educação ambiental}

A implantação de programas de uso público em unidades de conservação do Instituto Florestal teve início na Estação Experimental de Assis (SP), em 1978, afirma Tabanez (2000), com o intuito de atender às demandas para a utilização social de suas florestas, para atividades de educação ambiental para professores e estudantes e de recreação e lazer para a população em geral.

Segundo Garrido et al. (1982), o programa de uso público da Estação Experimental de Assis do Instituto Florestal, foi um projeto pioneiro que visava criar em suas unidades de conservação (estações experimentais), áreas de recreação e de educação ambiental. Esse programa foi implantado a partir de algumas adaptações aos povoamentos florestais existentes e com algumas construções ${ }^{25}$ necessárias ao bom atendimento do público visitante.

Os autores afirmaram que: a recreação em florestas homogêneas foi aceita pela população; que houve grande receptividade do Programa de Uso Público aplicado a escolares e que a conscientização dos visitantes quanto à preservação da área e do ambiente foi ampliada.

\footnotetext{
${ }^{24}$ LIMA, G.F. Questão ambiental e educação: contribuições para o debate. Ambiente \& sociedade, v 5, p.135-153, 1999.

${ }^{25}$ Foram implantados de maneira gradual: quiosques, churrasqueiras, lagos, sanitários, parque infantil, campo de futebol, teleférico, trilha de interpretação, trilha esportiva, centro cultural, enfermaria e estação do trenzinho florestal. (Garrido et al.,1992)
} 
As diretrizes específicas para os Programas de Uso Público do Instituto Florestal, segundo Tabanez (2000), têm por objetivo propiciar lazer, recreação e educação ambiental à comunidade, bem como despertar uma consciência crítica para a necessidade de conservação dos recursos naturais das unidades de conservação sob sua administração.

Definindo os subprogramas de educação ambiental, que compõem o Programa de Uso Público do Instituto Florestal, Tabanez \& Herculiani (1990 p.66) descrevem que: "ao se tratar da educação ambiental, deve-se levar em conta a Educação no seu sentido mais amplo. Considerando o processo educacional no Brasil desde o período colonial, nas diferentes fases: escola tradicional, escola nova, escola tecnicista às teorias crítico reprodutivistas".

As diretrizes que normatizaram, sistematizaram e direcionaram os programas de uso público no Instituto Florestal, segundo Tabanez (2000), foram definidas através de um processo participativo de educadores ambientais e diretores, membros de um grupo de educação ambiental, no início da década de 90.

Para Vasconcellos (2002, p.846), "o programa educativo é apenas um dos programas do Plano de Manejo da UC e deverá ser desenvolvido sempre de forma sistêmica em relação aos demais programas. Por maior que seja a demanda por uma determinada prática educativa, uma trilha interpretativa, por exemplo, sua implantação só deverá ser decidida com base na avaliação da capacidade de manejo e de gerenciamento existente".

Aoki \& Andrade (1997) realizaram um levantamento das atividades de uso público ${ }^{26}$ do Instituto Florestal, através das quais puderam verificar que estão sendo atingidos os objetivos de propiciar lazer, recreação e educação ambiental com os de preservar o seu imenso e valioso patrimônio natural.

\footnotetext{
${ }^{26}$ As Unidades de Conservação com Programas de Uso Público são: os parques estaduais Alberto Loefgren, Campos do Jordão, Cantareira, Carlos Botelho, Ilha Anchieta, Ilha Bela, Ilha do Cardoso, Jaraguá, Morro do Diabo, Porto Ferreira, Serra do Mar (Núcleos Caraguatatuba, Picinguaba e Santa Virgínia), Alto Ribeira e Vassununga; as estações ecológicas de Angatuba, Caetetus, Juréia-Itatins e Paulo Faria; as Florestas de Avaré e Manduri, e as Estações Experimentais de Assis, Itapetininga, Itirapina, Moji-Mirim, São José do Rio Preto e Tupi.
} 
Nesse trabalho, os autores verificaram que, os principais recursos utilizados são as trilhas interpretativas e os centros de visitantes. A maioria das trilhas destinadas a estudantes de $1^{\circ}$ e $2^{\circ}$ graus, são monitoradas e autoguiadas; as trilhas interpretativas ${ }^{27}$ e os centros de visitantes utilizados por estudantes de $1^{\circ}$ e $2^{\circ}$ graus e por professores, possibilitam a integração com os estabelecimentos de ensino.

A maioria dos centros de visitantes possui retroprojetor e projetor de slides como equipamentos básicos; alguns poucos, dispõem de filmadoras e videocassete. Em geral, o centro de visitantes é utilizado somente para recebimento de escolares e grupos organizados. Segundo Aoki \& Andrade (1997), o Programa de Uso Público do Instituto Florestal está plenamente consolidado, possibilitando a formação de uma consciência conservacionista na população, fundamental à preservação do patrimônio natural do Estado"

\section{EDUCAÇÃO AMBIENTAL E IMPLANTAÇÃO DE TRILHAS}

Segundo Sales \& Eston (2000), foi elaborado e posto em funcionamento no Parque Estadual "Alberto Loefgren" um roteiro interpretativo, voltado a estudantes do $1^{\circ}$ grau, das escolas públicas e particulares da cidade de São Paulo. Para a realização dessa atividade, implantou-se em 1999 a Trilha da Biosfera $^{28}$.

O levantamento preliminar das aves e dos mamíferos do Parque, segundo esses autores, forneceu subsídios para as atividades educacionais relacionadas à preservação da fauna. Os resultados, por sua vez, colaboraram para a elaboração de novas estratégias de atuação com escolares. A visita monitorada atingiu seus objetivos de contribuir para a conscientização dos

\footnotetext{
${ }^{27}$ Embora as trilhas estejam implantadas na maioria das unidades, destacam-se pela quantidade a E.E. Assis; os parques estaduais da Cantareira, Carlos Botelho, Ilha Anchieta, Morro do Diabo e Serra do Mar-Núcleo Picinguaba e Alto do Ribeira; e as estações ecológicas de Caetetus e Juréia-Itatins.

${ }^{28}$ No parque "Alberto Loefgrem", os estudantes são conduzidos ao Viveiro Florestal da Capital, ao Mirante das Capivaras. Em seguida, há uma área de piquenique e playground; posteriormente passam ao Museu Florestal "Octávio Vecchi". Depois, vão até o marco do Trópico Capricórnio. Em seguida, o grupo segue até o Palácio de Verão do Governado do Estado, finalmente, os estudantes chegam até uma área de lagos, formados pelo Córrego da Pedra Grande.
} 
alunos de escolas públicas e particulares de $1^{\circ}$ grau sobre a importância de se proteger a natureza e de se manter um meio ambiente equilibrado.

\section{EDUCAÇÃO AMBIENTAL E ESTRATÉGIAS DE ENSINO}

Tabanez et al. (1997) realizaram um estudo sobre a eficácia de diferentes estratégias utilizadas em trilhas interpretativas, em duas unidades de conservação, administradas pelo Instituto Florestal de São Paulo: Estação Ecológica de Caetetus e Estação Ecológica de Assis. O instrumento utilizado pelos autores, foi a aplicação de questionários escritos pré e pós-caminhada, testados previamente entre os alunos. As perguntas levantaram graus de conhecimentos e afetividade, assim como preferências, interesses e sugestões para a melhoria das trilhas.

Conclui-se nesse estudo que a metodologia adotada foi de grande relevância para mensurar a efetividade das diferentes estratégias educacionais utilizadas nas trilhas interpretativas. Os resultados indicaram que tanto a palestra preparatória como os slides e as visitas monitoradas às trilhas interpretativas são estratégias eficazes em educação ambiental e que qualquer das estratégias adotadas produz ganhos cognitivos e afetivos.

\section{EDUCAÇÃO AMBIENTAL E FORMAÇÃO DE PROFESSORES}

Maroti \& Santos (1997), realizaram um trabalho com o objetivo de caracterizar a percepção de um grupo (docentes do ensino fundamental) em uma unidade de conservação (Estação Ecológica de Jataí, SP). O instrumento básico para a coleta de dados foi representado por uma única questão associada a um mapa mental: "represente através de um desenho como é a Estação Ecológica em seu imaginário".

Através dos resultados obtidos, esperava-se a elaboração de estratégias para a implantação de um Programa de Educação Ambiental, através de uma abordagem interdisciplinar. O objetivo não se restringia a divulgar informações e conhecimentos fragmentados a respeito de uma área natural de conservação, 
mas sim trazer à tona problemas relacionados à importância e manutenção de uma área natural de conservação.

Um outro trabalho realizado, referente a educação ambiental e formação de professores foi realizado por Tabanez (2000). Com o objetivo de conhecer o significado que professores atribuem ao programa escolar orientado da Estação Ecológica dos Caetetus (EEC) e as contribuições do programa trazidas à prática profissional dos professores, bem como à valorização da unidade de conservação.

Os resultados indicaram que as concepções de meio ambiente da maioria dos professores se encontraram entre as tendências que a literatura designa como genérica e abrangente/alternativa (há uma preocupação, com raras exceções com os aspectos biológicos e ecológicos do meio ambiente) e tendência tradicional ou conservacionista. A participação dos professores configurou-se mais pela preparação dos alunos, nos aspectos logísticos e comportamentais, do que do ponto de vista pedagógico.

\section{EDUCAÇÃO AMBIENTAL E ECOTURISMO}

O Programa de Uso Público do Núcleo Picinguaba-Ubatuba, teve início em 1991com a função de planejar, regulamentar e desenvolver atividades que viabilizem o acesso público ao Parque, conforme os seus objetivos de manejo, e divulguem os atributos naturais e culturais existentes na área, mobilizando os visitantes e moradores locais acerca da importância da sua conservação.

A educação ambiental do Núcleo Picinguaba, segundo Simões et al. (2002), consiste no desenvolvimento de atividade de cunho predominante educativo, de estudo das características socio-ambientais do Parque, sempre monitoradas e voltadas para grupos organizados, escolares (do ensino básico ao superior), visitantes locais ou provenientes de outras cidades, e, ainda, de capacitação e formação de agentes difusores (educadores/alunos e lideranças comunitárias, jovens das comunidades moradoras no interior e entorno do Parque). 
As ações do subprograma de educação ambiental consistem em atendimento de grupos organizados, os quais procuram o Parque para realização de "estudo do meio", onde pernoitam ou passam o dia na sede. Essa atividade é predominante em todo o Programa de Uso Público, realizada de segunda a segunda, com uma média de dois grupos por semana, cada um cerca de 40 pessoas.

\subsection{Programa de Uso Público do Parque "Carlos Botelho": educação ambiental e lazer}

O Programa de Uso Público do Parque Estadual "Carlos Botelho", foi implantado com base nas experiências do Zoológico de Sorocaba-SP. Em meados da década de 80, segundo Ferraz \& Varjabedian (1999) foi realizado através da equipe do Zoológico "Quinzinho de Barros" de Sorocaba, um pedido de apoio financeiro junto ao World Wildlife Fund (WWF), para a implantação de projetos de educação ambiental.

Intermediado pela Fundação Pró-Natureza (Funatura), a liberação da verba ocorreu em 1987, e subsidiou projetos nessa frente, entre 1988 e meados de 1993, quando as atividades passaram a ser mantidas com o apoio da Fundação O Boticário de Proteção à Natureza; este último durou até 1994.

As iniciativas empreendidas nesse período foram realizadas no interior do Parque, foram desenvolvidas na área de uso público, que compreende aproximadamente 150 ha, localizados em sua porção norte. Nesta área, consolidou-se uma infra-estrutura básica para recepção e orientação de visitantes e passaram a ser utilizadas duas trilhas de interpretação: 1)Trilha Interpretativa do Taquaral e 2) Trilha Interpretativa do Açude.

Segundo Dias et al. (1986), foi elaborado um programa interpretativo a partir dos seguintes objetivos: desenvolver a apreciação do visitante na unidade ou área conservacionista; facilitar o trabalho do administrador na área conservacionista, assegurando a cooperação do público para o seu uso 
adequado e criar apoio político e popular para a instituição responsável pela administração da área.

No trabalho publicado por Vasaki et al. (1992), verifica-se que as atividades do Programa de Educação Ambiental do Parque Estadual "Carlos Botelho"- SP, teve como público-alvo a população de São Miguel Arcanjo, Capão Bonito e Sete Barras, municípios vizinhos ao Parque.

O objetivo principal desse trabalho, foi formar nas populações desses municípios, uma consciência crítica com relação aos problemas ambientais, dando ênfase àqueles ligados diretamente ao Parque. Buscou-se também, amenizar os problemas de invasão da área, divulgar o Parque e os benefícios que este traz à comunidade, informar a população sobre a situação da fauna e flora da região, destacando a importância do Parque e abrir oportunidade de lazer e recreação, principalmente à população circunvizinha.

Vasaki et al. (1992) citam que foram realizadas as seguintes atividades no Parque: visitas monitoradas: palestras, projeção de slides, visita ao museu de zoologia, caminhada em trilhas no interior da mata e lazer orientado; educação ambiental: com grupos de alunos de escolas rurais; curso para professores com atividades práticas e teóricas; atividades junto à comunidade: levantamento da fauna e flora; palestras: preparação para a visita ao Parque; curso de ecologia por correspondência; concursos: de fotos, redação, desenhos junto às escolas; gincanas: na semana do meio ambiente, da árvore e da criança; participação em eventos cívicos; divulgação através da imprensa local; distribuição de material de divulgação. 


\section{METODOLOGIA}

\subsection{Pesquisa Qualitativa}

Segundo Ludke \& André (1986), é cada vez mais evidente o interesse que os pesquisadores da área de educação vêm demonstrando pelo uso de metodologias qualitativas. Dentre as características básicas que compõem essa metodologia, esses autores destacam: o interesse do pesquisador ao estudar um determinado problema é verificar como ele se manifesta nas atividades, nos procedimentos e nas interações cotidianas"; nesses estudos há sempre uma tentativa de capturar a "perspectiva dos participantes", isto é, a maneira como os informantes encaram as questões que estão sendo focalizadas.

Para Alves Mazzotti (1998), enquanto os pós-positivistas trabalham com projetos bem detalhados, os construtivistas sociais defendem um mínimo de estruturação prévia, considerando que o foco da pesquisa, bem como as categorias teóricas e o próprio design só deverão ser definidos no decorrer do processo de investigação.

\subsection{Estudo de caso}

De acordo com Yin (1990), o estudo de caso é usado preferencialmente no exame de eventos contemporâneos, quando os comportamentos não podem ser manipulados. Essa técnica é a única suficientemente habilitada para lidar com uma grande variedade de evidências - documentos, artefatos, entrevistas e observações.

Segundo Ludke \& André (1986), o interesse por esse método se dá quando a proposta incide naquilo que o caso tem de único, de particular, 
mesmo que posteriormente venham a ficar evidentes certas semelhanças com outros casos e situações. Assim, as características fundamentais do estudo de caso se superpõe às características gerais da pesquisa qualitativa, entre estas destacam-se:

a)a descoberta diante do pressuposto de que o conhecimento não é algo acabado, mas uma construção que se faz e refaz constantemente;

b)é levado em conta o contexto em que o caso se situa para que se compreenda melhor a manifestação geral de um problema;

c)busca retratar a realidade de forma completa e profunda, focalizando-o como um todo;

d)usa uma variedade de fontes de informação e variados informantes; assim será possível que o pesquisador cruze diferentes informações.

\subsection{Procedimentos}

Ludke \& André (1986), caracterizam o desenvolvimento do estudo de caso em três fases:

a) Primeira: aberta ou exploratória. É baseada num plano incipiente; em questões ou pontos críticos iniciais; pode ter origem no exame da literatura pertinente; pode ser fruto de observações e depoimentos feitos por especialista sobre o problema; pode surgir de um contato inicial com pessoas ligadas ao fenômeno estudado ou da especulação baseada na experiência pessoal do pesquisador.

b) A segunda fase do método de estudo de caso tem uma preocupação mais centrada nas características próprias do objeto de estudo. Os instrumentos podem ser mais ou menos estruturados, as técnicas mais ou menos variadas. Porém, nessa fase, a coleta deve ser mais sistemática, como afirmam os autores.

c) A terceira fase do estudo de caso constitui-se na análise e interpretação sistemática dos dados e na elaboração do relatório, lembrando 
que essas três fases se superpõem em diversos momentos, sendo difícil precisar as linhas que as separam.

\subsection{Coleta de dados}

NO INTERIOR DO PARQUE "CARLOS BOTELHO”

Foi utilizada a observação direta sobre as atividades educativas ambientais realizadas no Parque, associada à composição de um caderno de campo, onde se registrou o cotidiano da Unidade de Conservação, no programa de educação ambiental e visitação pública, durante um ano (setembro de 1999 a novembro de 2000).

Após três meses de vivência no Parque, passou a ser empregada a técnica de análise documental, entre esses, decretos de criação, leis, atas de reunião; relatórios das ações educativas e vídeos institucionais do Parque. Os documentos foram catalogados em fichas, sendo detalhadas as referências do documento e o resumo do seu conteúdo, destacando os trechos onde se deflagram, principalmente, ações e diretrizes ligadas ao Programa de Uso Público.

Após três meses na área de estudo, a inserção no grupo permitiu, além da vivência no programa de educação ambiental, a aplicação de outras técnicas de coleta de dados específicas para estudo de caso: registros fotográficos das atividades de manejo do uso público e educação ambiental e registro de reuniões da equipe do programa de educação ambiental e de uso público.

\section{NO ENTORNO DO PARQUE "CARLOS BOTELHO”}

A ênfase dada ao município de São Miguel Arcanjo e não aos demais municípios circunvizinhos ao Parque: Capão Bonito, Sete Barras e Tapiraí, ocorreu em função da precariedade logística. No município de São Miguel Arcanjo, sede do Parque Estadual "Carlos Botelho", foram realizadas, no período de setembro de 2002 a março de 2003, entrevistas semi-estruturadas 
com dois tipos de informantes: que tiveram vínculos com o programa de administração e vigilância e também ligados à rede de extração de palmito.

Segundo Marconi (1999), a entrevista, que visa a obter respostas válidas e informações pertinentes, é uma verdadeira arte, que se aprimora com o tempo, com treino e com experiência. Exige habilidade e sensibilidade; não é tarefa fácil, mas é básica. Para maior êxito da entrevista, devem-se observar algumas normas:

1- Contato inicial: o pesquisador deve entrar em contato com o informante e estabelecer, desde o primeiro momento, uma conversa amistosa, explicando a finalidade da pesquisa, seu objeto, relevância e ressaltar a necessidade da colaboração.

2- Formulação de perguntas: devem ser feitas de acordo com o tipo de entrevista: padronizadas e não padronizadas. Para não confundir o entrevistado, deve-se fazer uma pergunta de cada vez.

3- Registro de respostas: as declarações devem ser anotadas no momento da entrevista, para maior fidelidade e veracidade das informações. $O$ uso do gravador é ideal se o informante concordar com a sua utilização.

4- Término da entrevista: a entrevista deve terminar como começou, para que o pesquisador, se necessário, possa voltar e obter novos dados sem que o informante se oponha a isso.

5- Requisitos importantes: as respostas de uma entrevista devem atender aos seguintes requisitos: validade, relevância, especificidade e clareza, cobertura da área, profundidade e extensão.

As entrevistas foram registradas tendo o gravador como instrumento de coleta, somente três entrevistados não autorizaram a gravação, por motivos pessoais: o "atravessador" de palmito, um antigo funcionário do Parque e o delegado de São Miguel Arcanjo.

A Polícia Ambiental de Itapetininga-SP colaborou neste trabalho com o fornecimento de dados referentes à apreensão de palmito no interior do Parque "Carlos Botelho" e nos municípios de São Miguel Arcanjo e Juquiá. Esses 
dados foram enviados via fax, após cinco ligações de esclarecimento sobre os objetivos da pesquisa e de que maneira esses dados seriam apresentados.

A Polícia Ambiental de Registro-SP, também colaborou disponibilizando dados de apreensão de palmito no Parque Estadual "Carlos Botelho" e no Parque Estadual Intervales. A obtenção dessas dados partiu do envio de uma carta de solicitação endereçada, via fax, ao responsável pela unidade administrativa da polícia.

\subsection{Análise e interpretação dos dados}

Nessa fase da pesquisa, Ludke \& André (1986), sugerem que os "rascunhos" de relatórios podem ser apresentados por escrito ou constituir-se em apresentações visuais, auditivas, etc. Evidentemente, os procedimentos não se completam numa seqüência linear, mas se interpolam em vários momentos, sugerindo apenas um movimento constante no confronto teoria-empírico.

Analisando as evidências do estudo de caso, Yin (1990), sugere algumas técnicas analíticas entre estas: colocar a informação em diferentes matrizes; fazer uma matriz de categorias e colocar as evidências dento dessa categoria; colocar as informações em ordem cronológica ou usar algum outro esquema temporal.

Alves Mazzotti (1998) afirma que pesquisas qualitativas tipicamente geram um enorme volume de dados que precisam ser organizados e compreendidos. Esse é um processo complexo, não-linear, que implica um trabalho de redução, organização e interpretação dos dados que se inicia já na fase exploratória e acompanha toda a investigação.

\subsection{Cenário de Estudo}

No alto da serra de Paranapiacaba, encontra-se o município de São Miguel Arcanjo, que foi fundado, segundo Barbas (1998), pelo Tenente Urias Emygdio Nogueira de Barros; o que não quer dizer que foi este e sua família os primeiros moradores locais. A área comprada pelo Tenente Urias poderia ser 
descrita, da seguinte maneira: um imenso retângulo de 12 quilômetros de largura, na direção leste- oeste e de 20 quilômetros de norte a sul, nas nascentes do rio Paranapanema, sul do Estado de São Paulo.

O rio Paranapanema nasce no planalto, junto à Serra do Mar, que neste trecho chama-se Serra de Paranapiacaba (em linguagem nativa: lugar onde se vê o mar); corre para o interior, indo desaguar no rio Paraná. Nas proximidades de sua nascente, recebe águas de vários afluentes que, por assim dizer, ajudam-no a se formar. Um destes é o rio Turvo que, por sua vez, é formado por vários afluentes, inclusive o rio São Miguel Arcanjo.

Segundo Ferraz (1999) o município de São Miguel Arcanjo localizado ao sul do Estado de São Paulo, tem como limite ao sul os municípios de Tapiraí e Sete Barras, ao norte Itapetininga, à leste Capão Bonito e à oeste Pilar do Sul. Oferece temperatura agradável com média de $18^{\circ} \mathrm{C}$ a $19^{\circ} \mathrm{C}$, máxima de $28^{\circ} \mathrm{C}$ e mínima de $3^{\circ} \mathrm{C}$ com possibilidades de geadas fracas e fortes.

Com uma população de aproximada de 27.485 indivíduos, distribuídos em 16.416 pessoas na zona urbana e 11.069 pessoas na zona rural (BrasilIBGE, 2003), a sustentação econômica de São Miguel Arcanjo baseia-se na agricultura e pecuária, destacando-se: uva Itália, uva Niágara, uva Rubi e uva Benitaka. Destaca-se também a produção de batata inglesa. O município de São Miguel Arcanjo, não dispõe de investimento no setor industrial, o que torna o município carente de empregos, gerando um grande problema social.

Para Ferraz (1999) a utilização de mão-de-obra é familiar e ocorre normalmente nos meses de outubro a março. Em outros períodos do ano existe ociosidade dessa mão-de-obra e uma pequena parte consegue trabalho em outras culturas agrícolas. O caráter sazonal da agricultura estimula o trabalho sem vínculo empregatício. Uma alternativa seria o incentivo ao ecoturismo. Isso permitiria o aproveitamento do potencial turístico voltado às belezas naturais da região e, consequentemente, permitiria a abertura de postos de trabalho.

No município de São Miguel Arcanjo está localizada a sede do Parque Estadual "Carlos Botelho", segundo Ferraz \& Varjabedian (1999). O Parque 
apresenta duas características que o diferencia das demais unidades de conservação que compõem o continuum ecológico da Mata Atlântica: a questão da regularização fundiária praticamente resolvida e a inexistência de população residente no seu interior. (exceto o caso de funcionários que estão a serviço da unidade)

No que refere-se à população que ocupa as porções do entorno do Parque, esses autores apresentaram duas áreas distintas com realidades e características muitos específicas: a que pertence aos municípios de Sete Barras e Tapiraí, no Vale do Ribeira e a que inclui São Miguel Arcanjo e Capão Bonito, no Alto da Serra de Paranapiacaba, na área que pertence a Bacia do rio Paranapanema.

\subsection{Sujeitos da pesquisa}

De modo a preservar a identidade dos informantes, os mesmos serão apresentados com nomes fictícios, bem como ordenados por tipo de envolvimento com o tema em questão.

NO PARQUE "CARLOS BOTELHO”: ex-funcionário

Abrãao: 78 anos, casado três filhos, ex-funcionário da fiscalização do Parque, onde trabalhou 36 anos, residente no Bairro Abaitinga. Aposentado, nasceu em Sete Barras, onde morou por mais de 20 anos, alguns familiares vivem da extração clandestina de palmito. Funcionário de muita confiança do antigo diretor do Parque (décadas de 70 e 80), no tempo em que a área ainda era denominada reserva florestal.

NO PARQUE "CARLOS BOTELHO": ex-funcionário

Abel: 67 anos, nenhum filho formou-se em engenharia agronômica e cresceu no campo, nasceu em Taubaté. Trabalhou em dois órgãos ambientais: IAC (Instituto Agronômico de Campinas) e Estação Experimental de TaubatéInstituto Florestal. Em 1971, foi escolhido para administrar o Parque "Carlos Botelho". Atualmente reside em São Miguel Arcanjo e está aposentado. 
NA REDE CLANDESTINA DE PALMITO: vendedor

Mateus: 62 anos, lavrador, casado, dois filhos, $1^{\circ}$ grau incompleto, residente em São Miguel Arcanjo desde criança. Trabalhou junto à equipe de topografia que faz o divisor do Parque "Carlos Botelho", atualmente vende palmito para consumidores residentes em São Miguel Arcanjo e trabalha no comércio local.

NA REDE CLANDESTINA DE PALMITO: consumidora

Maria: 35 anos, noiva, residente em São Miguel Arcanjo, $2^{\circ}$ grau completo, quatro irmãos, pequena empresária numa marcenaria familiar, não tem filhos, atua como marceneira há 10 anos. Consumidora esporádica de palmito juçara, comprando o produto com extratores locais ou ganhando do irmão.

\section{NA REDE CLANDESTINA DE PALMITO: consumidora}

Isabel: 51 anos, casada, nenhum filho, oito irmãos, residente em São Miguel Arcanjo, $1^{\circ}$ grau completo. Doméstica, catequista na igreja católica, casada com um funcionário de uma reflorestadora. Consumidora de palmito, pois quando ocorre alguma derrubada no local onde o marido trabalha, este é distribuído entre os funcionários.

NA REDE CLANDESTINA DE PALMITO: consumidora

Madalena: 29 anos, casada, sem filhos, $3^{\circ}$ grau completo, filha única, formada em administração de empresas, passou a infância e adolescência em São Miguel, mas atualmente reside em Sorocaba; participou das excursões monitoradas realizadas no Parque estudado. Consumidora de palmito, comprando dos extratores que vendem em São Miguel.

NA REDE CLANDESTINA DE PALMITO: extrator

Pedro: 18 anos, solteiro, sem filhos, sete irmãos, residente no município de Juquiá, $1^{\circ}$ grau incompleto, pequeno proprietário. Desempregado, filho de mecânico, passou a infância em Juquiá e vive de "bicos" e da extração clandestina de palmito na região do Baixo Vale do Ribeira. 
NA REDE CLANDESTINA DE PALMITO: extrator

Tiago: 18 anos, solteiro, sem filhos, três irmãos, residente no município de Juquiá, $1^{\circ}$ grau incompleto. Pequeno proprietário, desempregado, passou a infância em Juquiá, atualmente extrai palmito para ajudar a mãe que está com câncer e não é aposentada.

NA REDE CLANDESTINA DE PALMITO: advogada

Ester: 48 anos, casada, sem filhos, $3^{\circ}$ grau completo, formada em direito pela PUC de Sorocaba-SP, residente em São Miguel Arcanjo. Profissional liberal, esta é a advogada mais procurada por extratores apreendidos na delegacia de São Miguel Arcanjo.

NA REDE CLANDESTINA DE PALMITO: "atravessador"

Lucas: 35 anos, divorciado, uma filha, $1^{\circ}$ grau completo, reside em Itapetininga, mas possui casa no Baixo Vale do Ribeira, Iporanga-SP. Tem uma oficina mecânica e mora com os pais, já foi preso por porte ilegal de arma e carregamento de palmito no município de Eldorado.

NA REDE CLANDESTINA DE PALMITO: delegado

João: 52 anos, solteiro, nenhum filho, $3^{\circ}$ grau completo, formado em direito, delegado de polícia de São Miguel Arcanjo, residente no município. Viveu muitos anos no município de Ribeirão Grande, sede do PE Intervales, onde acompanhou mais de perto a rota da extração clandestina de palmito. 


\section{RESULTADOS E DISCUSSÃO}

Apresentam-se neste item os resultados e a discussão sobre os planos de gestão e as ações de educação ambiental do PE "Carlos Botelho" e suas interferências na extração clandestina de palmito (Euterpe edulis) ocorrida nesta região. Assim, os resultado serão desse trabalho serão apresentados a partir de uma matriz de categorias que definem a realidade estudada, entre essas a gestão administrativa, os planos e ações educativas e as políticas de enfrentamento da extração clandestina de palmito evidenciada no interior da Unidade de Conservação.

Nesta apresentação serão utilizados os documentos coletados, trechos de depoimentos e entrevistas, bem como os registros do caderno de campo, aportado nos teóricos que permitiram a compreensão do universo da pesquisa. Nessa tarefa, busca-se apoio teórico em autores que tratam da educação ambiental e em outros, que contribuíram para a definição de conceitos de homem, floresta e sociedade.

\subsection{Políticas de gestão no Parque Estadual "Carlos Botelho"}

No momento em que se adentra a uma Unidade de Conservação, consta-se, como afirmou Pimbert \& Pretty (2000), que os métodos e meios usados para conservar áreas naturais e selvagens (originados no Ocidente) giram em torno de capital e pessoal treinado. Esses, irão assegurar que tecnologias tenham bom desempenho e que a legislação seja respeitada para conseguir o objetivo da conservação.

Um exemplo dessa afirmativa pode ser evidenciado nas primeiras reuniões que estabeleceu um convênio de apoio financeiro às unidades de 
conservação do Vale do Ribeira, incluindo todos os parques do Alto e Baixo Vale do Ribeira. Trata-se do convênio ligado ao Programa de Preservação da Floresta Tropical (Mata Atlântica) em cooperação financeira entre o governo brasileiro e o Kreditanstalt für Wiederaufbau (KFW), da Alemanha.

Esse apoio visava à elaboração de planos de manejo, apoio à educação ambiental, ecoturismo e fiscalização em todas as áreas e consolidação das unidades. A administração do Parque estava ciente que esse apoio externo permitiria ações pontuais e que manteria o Parque durante alguns anos. Por outro lado, sem esse tipo de apoio externo, seria quase impossível administrar os parques, pois o dinheiro do órgão responsável pelo Parque, neste caso o Instituto Florestal, responde à demanda operacional básica como manutenção de equipamentos, fiscalização e folha de pagamento dos funcionários, de acordo com Brito (2000).

As ações que são desenvolvidas nos parques dependem de investimento externo, ou seja, do estabelecimentos de convênios e parcerias. Esse tipo de plano tem visado a atender à necessidade de melhoria da infra-estrutura do parque.

O convênio com o KFW visa, entre outros aspectos, à elaboração do plano de manejo do parque. Assim, nos anos 1999 e 2000, o administrador do parque apresentou algumas propostas num encontro preliminar das unidades de conservação, junto à equipe gestora dos planos de manejo financiados pelo Banco KFW. As propostas do parque visando à política de gestão administrativa estruturaram-se em objetivos e entre esses:

- otimizar as rotinas administrativas: operacionalizando a execução dos programas de manejo da Unidade de Conservação; descentralizando a estrutura administrativa com a implantação de um escritório no Núcleo Sete Barras (setor sul do parque); recuperando os divisores na região do entorno nos municípios de Sete Barras e Juquiá ; 
- fortalecer a educação ambiental e o manejo da visitação ${ }^{53}$ : conscientizando a população sobre a importância da UC, para a conservação dos recursos naturais; incentivando processos de melhoria da sustentabilidade do Parque e da comunidade do entorno; expandindo as atividades ao público visitante no entorno e região no núcleo Sete Barras (setor sul do Parque); efetivando a implantação de uma 'estrada parque'; implantando o núcleo de Capão Bonito.

- apoiar o desenvolvimento de pesquisa: elaborando e implantando um banco de dados contendo informações sobre as pesquisa realizadas no Parque e em andamento;

-incentivar o programa de fiscalização: continuando e aperfeiçoando a execução do plano de fiscalização integrada em conformidade com o previsto no P.O.C. (plano operacional de controle); otimizando a execução de trabalho conjunto de fiscalização entre os parques estaduais da região; implantando os procedimentos de fiscalização com os proprietários das áreas do entorno.

A administração tem idéias bastante progressistas no que diz respeito aos planos e ações que visam à conservação e está se dispondo a buscar apoio junto à iniciativa privada e demais setores da sociedade. Isso faz de 'Carlos Botelho' um parque que está evoluindo na direção de novos modelos de conservação, no sentido de buscar a integração, a articulação entre setores e, por fim, a sustentabilidade.

A criação de um escritório no núcleo Sete Barras seria um primeiro passo na direção de encaminhar ações que não desacatem as ordens da instância superior, mas que nesse sentido abram 'picadas' em direção a novos modos de sustentação da vida ${ }^{54}$.

\footnotetext{
53 Entre as ações voltadas ao fortalecimento do programa de manejo do uso público do parque, está a capacitação de monitores ambientais, para atuar na recepção e orientação de visitantes no interior do parque. Pois a administração do parque acredita que, a expansão do turismo na região demandará mão de obra especializada e infra-estrutura adequada. O programa de uso público do parque, estrutura-se nessa direção, maiores detalhes dessa ação encontra-se no apêndice 1.

54 Para que não haja uma cópia autêntica do programa de educação ambiental e visitação pública realizado no setor norte e sede do parque, primeiramente, dever-se-ia procurar saber se a população está devidamente informada sobre o que representa a extração clandestina de palmito e o por quê se continua alimentando essa prática.
} 
A efetivação de uma 'estrada parque' permitirá que o Parque materialize, em parte, os seus desejos de ser um pólo gerador de desenvolvimento, uma vez que a abertura poderá permitir um fluxo maior de visitantes, além do que facilitará o contato dos setores norte e sul do Parque.

Mesmos as questões ligadas ao programa de fiscalização do Parque apresentam conceitos bastante inovadores no plano de gestão. Propõem-se a realizar uma fiscalização integrada e implantar os procedimentos de fiscalização com os proprietários das áreas do entorno. Isso revela uma visão integrada sobre a Unidade de Conservação, vinculado-a à sociedade na qual o Parque está inserido.

Considerando essas ponderações, será oportuno considerar a afirmação de Manniguel et al. (2002), de que a criação de unidades de conservação tem sido uma das alternativas para a proteção da biodiversidade em várias partes do mundo. No entanto, esse modelo de conservação tem se confrontado com concepções locais de uso dos recursos naturais e ocupação do solo. Deste modo, configura-se um possível foco de conflito, cuja prevenção e resolução têm sido atribuídas ao estabelecimento de parcerias e de uma política participativa $^{55}$.

Resgatando o estabelecimento de parceria, esses autores afirmam que tem sido efetivado, desde 1995, no âmbito de cooperação técnica internacional entre Brasil e Alemanha, o projeto Doces Matas, com a meta de estabelecer um sistema participativo de manejo para a proteção da biodiversidade. Esse nome se deu em função do projeto estar sendo desenvolvido em alguns remanescentes da Mata Atlântica na Bacia do Rio Doce, sendo um projeto associado ao Programa Piloto para as Florestas Tropicais (PPG7).

\footnotetext{
${ }^{55}$ Segundo Pimbert \& Pretty, citados por Mannigel et al. (2002), é importante se ressaltar que o termo participação tem uma conotação muito ampla e tem sido utilizado para se referir tanto a um mero repasse de informações quanto a um envolvimento mais pleno, pautado pela interação dos atores envolvidos no processo e pelo seu poder decisório. Portanto, a plena prática da reflexão e análise do processo participativo instaurado podem ser uma forma de garantir que os objetivos de descentralização, envolvimento, democracia na gestão das UC's, não se percam e se desvirtuem em rumos opostos aos pretendidos.
} 
Entre os resultados desses autores, verificou-se que uma as grandes transformações que tem sido destacadas pelos próprios técnicos das instituições que manejam as áreas protegidas são as suas próprias mudanças de atitude em relação às comunidades e instituições do entorno. O agricultor não é mais visto só como o infrator, mas também como cidadão. Isso facilita a cooperação e aumenta a motivação da equipe das UC's. Segundo os autores, a participação como integrante da vida social no Brasil é ainda uma realidade muito recente.

\subsection{Extrativismo nas unidades de conservação de proteção integral do Alto Vale do Ribeira}

Apesar de não permitir grandes mudanças no contexto regional como almejava a administração, o convênio do Parque com o Banco Alemão (KFW) esse convênio reforçaria as ações de fiscalização do Parque, que, naquele momento, estava desgastada pela mídia paulistana que a cada dia lançava em cadeia nacional artigos denunciando a destruição da Floresta Atlântica, bem como a invasão de palmiteiros nas unidades de conservação do Alto Vale do Ribeira.

Segundo Ferraz \& Varjabedian (1999), foi elaborado um mapa tendo como fonte a vivência de uma equipe de pesquisadores do Instituto Florestal na área. Essa equipe, a partir da documentação do programa de fiscalização, procurou identificar as áreas do entorno do Parque, estabelecendo uma hierarquização dos vetores de pressão. Essa classificação se deu com base na intensidade das ações, no número de ocorrências e no tipo de pressão.

Os resultados desse trabalho revelaram seis áreas consideradas críticas do ponto de vista da pressão sobre os recursos: Saibadela, Guapiruvu, Grota, Rio Preto, Travessão e Ribeirão Fundo. Esses locais de pressão são áreas onde a rede organizada de palmiteiros atua de maneira intensa; a invasão do Parque para a retirada de palmito ocorre amparada por forte esquema armado, com pistoleiros especialmente contratados para esse fim. Praticamente todos 
os bairros do entorno participam, direta ou indiretamente, da atividade, motivados pela situação de precariedade socioeconômica de toda a região. Nesses bairros realizam o beneficiamento do palmito e preparação para a comercialização, muitas vezes sem condições mínimas de higiene.

Segundo esses autores, as áreas localizadas no planalto, setor norte do Parque, apresentam um perfil diferenciado. Apesar da ocorrência periódica de invasão do Parque para a retirada de palmito, da ação igualmente constatada de participação dos bairros do entorno no beneficiamento e comercialização, a intensificação da atividade extrativista é menor.

Dados fornecidos pela Polícia Ambiental de Registro-SP (2003), indicam os números de apreensões de palmito (Euterpe edulis) no período de 2002 e $1^{\circ}$ semestre de 2003, nas áreas dos Parques Estaduais "Carlos Botelho" e Intervales.

\begin{tabular}{|l|l|}
\hline PARQUE ESTADUAL “CARLOS BOTELHO” & PARQUE ESTADUAL INTERVALES \\
\hline Palmito in natura: 183 & Palmito in natura: 1326 \\
\hline Palmito industrializado: 350 vidros. & Palmito industrializado: 877 vidros. \\
\hline
\end{tabular}

Quadro 2 - Apreensão de palmitos em UC's do Vale do Ribeira

Fonte: Polícia Ambiental de Registro-SP

Seria oportuno observar, que o número de palmito extraído no Parque Estadual Intervales é superior, ao volume retirado do Parque Estadual "Carlos Botelho". Esses dados confirmam as afirmações feitas no trabalho de Ferraz \& Varjabedian (1999) indicando que, na região sul, o vetor de pressão é bem mais acentuado. O Parque Estadual Intervales faz fronteira com o parque estudado. 


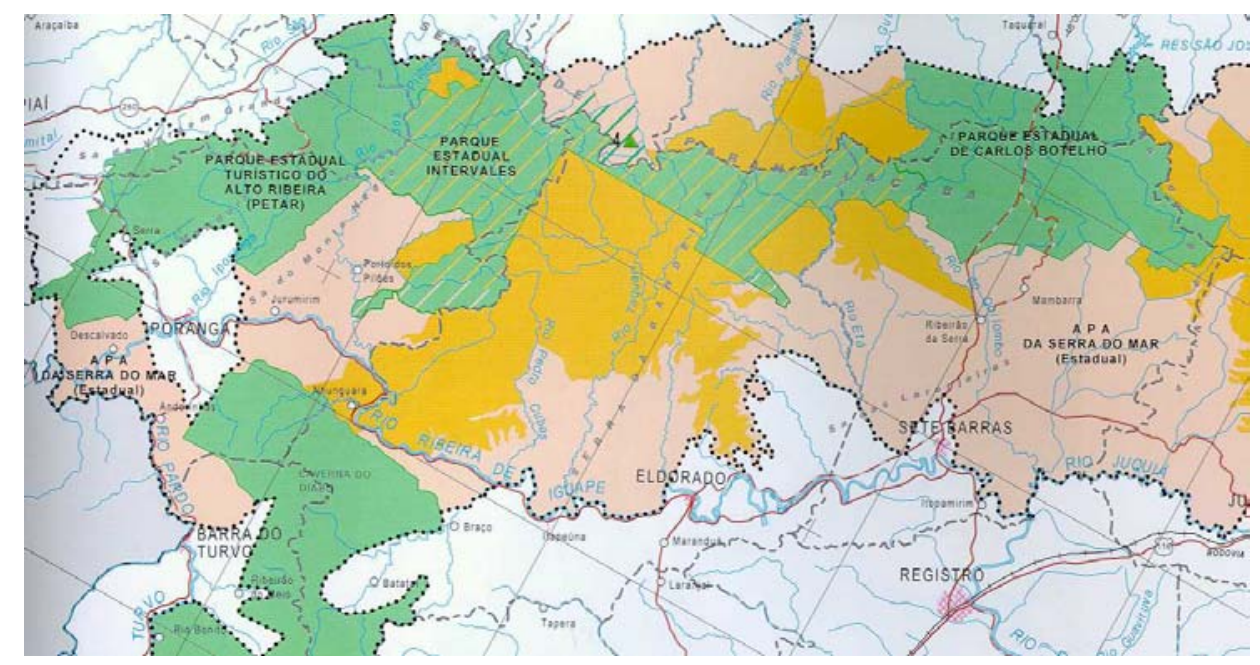

Figura 1- Mapa de localização dos parques "Carlos Botelho" e Intervales Fonte: Mapa da Unidades de Conservação do Estado de São Paulo.

Dados fornecidos pela Polícia Ambiental de Itapetininga-SP indicam apreensões de palmito Euterpe edulis nos anos de 2000, 2001, 2002 e 2003 nos municípios de São Miguel Arcanjo e Juquiá, bem como no interior do Parque Estadual "Carlos Botelho". Além dos dados de apreensão, a Polícia forneceu também o total dos autos de infração. 


\begin{tabular}{|c|c|c|c|}
\hline OCORRÊNCIA & LOCAL & TOTAL & ANO \\
\hline $\begin{array}{l}\text { Extração, transporte e } \\
\text { armazenamento de } \\
\text { palmitos }\end{array}$ & $\begin{array}{l}\text { PE "Carlos Botelho" } \\
\text { abrangendo } \\
\text { município de Juquiá }\end{array}$ & 03 & 2000 \\
\hline $\begin{array}{l}\text { Extração, transporte e } \\
\text { armazenamento de } \\
\text { palmitos }\end{array}$ & $\begin{array}{l}\text { PE "Carlos Botelho" } \\
\text { abrangendo o } \\
\text { município de Juquiá }\end{array}$ & 11 & 2001 \\
\hline Extração de palmitos & $\begin{array}{l}\text { PE "Carlos Botelho" } \\
\text { abrangendo o } \\
\text { município de Sete } \\
\text { Barras }\end{array}$ & 01 & 2001 \\
\hline Extração de palmitos & $\begin{array}{l}\text { PE "Carlos Botelho" } \\
\text { abrangendo o } \\
\text { município de Juquiá }\end{array}$ & 02 & 2002 \\
\hline Extração de palmitos & $\begin{array}{l}\text { PE "Carlos Botelho" } \\
\text { abrangendo o } \\
\text { município de Juquiá }\end{array}$ & 02 & 2002 \\
\hline $\begin{array}{l}\text { Extração, transporte e } \\
\text { armazenamento de } \\
\text { palmitos }\end{array}$ & $\begin{array}{l}\text { PE "Carlos Botelho" } \\
\text { abrangendo o } \\
\text { município de São } \\
\text { Miguel Arcanjo }\end{array}$ & 17 & 2003 \\
\hline $\begin{array}{l}\text { Armazenamento de } \\
\text { palmitos }\end{array}$ & $\begin{array}{l}\text { PE "Carlos Botelho" } \\
\text { abrangendo o } \\
\text { município de Sete } \\
\text { Barras }\end{array}$ & 01 & 2003 \\
\hline
\end{tabular}

Quadro 3 - Apreensões de extração, transporte e armazenamento de palmito no PECB Fonte: Polícia ambiental de Registro (2003)

Segundo a Secretaria do Meio Ambiente de São Paulo (1998), o extrativismo de produtos florestais, muito freqüente na região do Vale do Ribeira, quase sempre é realizado de forma ilegal. Por essa razão, torna-se difícil quantificar essa atividade, exceto pela pequena parcela autuada pelos órgãos de fiscalização. Os dados levantados mostram que o principal produto de extrativismo florestal da região é o palmito, em geral, retirado ilegalmente pela população rural e vendido a fábricas clandestinas ou regularizadas.

A proposta dessa Secretaria é, em primeiro lugar, gerar renda para o pessoal de baixa renda, retomando a idéia da sustentabilidade. Para tanto, propõe uma negociação social e já está, inclusive, levantando qual é o estoque 
de palmito. Posteriormente, irá saber se há condições de colocar no mercado um produto legal. Existe uma pressão para que se atenda a esse mercado e, segundo a Secretaria, no momento em que houver oferta do produto legalizado, ter-se-ão condições de impedir o mercado ilegal, do palmito que hoje é clandestinamente coletado.

A afirmação dessa Secretaria, contrariou a postura do conselho técnico do Instituto Florestal, órgão da Secretaria do Meio Ambiente de São Paulo, que vetou o plano de manejo sustentado com o objetivo de evitar a extinção da palmeira juçara na mata Atlântica. Segundo Tomazela (2002) esse plano idealizado por ambientalistas, chegou a ser aprovado pelo antigo secretário do Meio Ambiente, Sr. Ricardo Tripoli.

Esse autor afirmou que o principal entrave desse foi veto, foi a previsão de coleta de sementes no interior dos parques estaduais Carlos Botelho e Intervales, o que é proibido por lei. A legislação federal, que instituiu o Sistema Nacional de Unidades de Conservação (Brasil - SNUC, 2003), veta qualquer outro tipo de atividade nos parques, a não ser a pesquisa científica e recreação (grifo nosso). Mas que é possível colher semente fora da reserva e que o Instituto Florestal tem interesse em trabalhar com as comunidades do entorno.

Desse modo é oportuna a afirmação de Pimbert \& Pretty (2000) de que, por todo o mundo, políticas de conservação têm sido baseadas na visão predominante de que as populações rurais não são boas gestoras dos recursos naturais. Isso é um grande perigo da ideologia da conservação. Eventualmente, isso conduz à coerção e essa não é a base para o manejo sustentável dos recursos naturais.

Nas entrevistas realizadas, verificou-se que desde o extrator até o consumidor, todos concordaram que a extração do palmito deve ser proibida com policiais nas divisas do parque.

Segundo o vendedor Mateus "se essa prática não for proibida, fica ruim para nós (vendedores clandestinos) porque a população que vive da extração, acaba com as espécies em questão de meses. Cortarão todo o palmito que 
virem pela frente, matarão os bichos e acabarão com a natureza". Esse informante, legitima o papel controlador que a fiscalização representa e mesmo numa visão utilitarista frente a natureza, percebe a insustenbalidade da espécie.

O extrator Pedro disse: "a prática da extração é proibida, por isso são poucos os que se aventuram a entrar no mato. Se fosse liberado não teria um pé de palmito". A clandestina favorece a rede da extração de palmito e onde o palmiteiro mesmo segregado, recebe o seu salário. Este também legitima o papel da fiscalização, por questões utilitaristas; demonstrando que essa prática é uma realidade na região.

O 'atravessador' Lucas disse que "essa prática tem a lógica do tráfico de entorpecentes, corre-se um risco e esse risco é grande. Mas se a polícia não pegar, no mês dá para ganhar um valor correspondente a $\mathrm{R} \$ 5$ mil reais". Notase nesse cenário, a presença de pessoas com interesses diversos. Suas falas sugerem inseguranças e incertezas em diferentes níveis, evidenciando desde uma preocupação com a escassez do recurso florestal até o risco que correm frente à ação clandestina.

As consumidoras entrevistadas: Maria, Isabel e Madalena, sentindo-se envergonhadas ao dizer que compram o produto no vidro ou in natura, revelaram desconhecer essa rede que sustenta a extração clandestina. Maria afirmou: "o palmito já estava cortado, se estes não forem comprados por nós, outros provavelmente o comprariam". Essas consumidoras afirmaram ter participado de ações educativas no interior no entanto, mas desconhecem o que seria o manejo sustentável de palmito.

No município de São Miguel Arcanjo foram encontradas duas famílias que vivem da extração, neste trabalho optou-se por não as entrevista-las após a informação tanto na delegacia, como por moradores locais, de que essas famílias são envolvidas com roubo de carro e de aparelhos eletrodomésticos.

O vendedor Mateus, disse saber da proibição da extração, no entanto, afirmou: "eu era muito amigo do antigo diretor do parque, porque eu atuava junto com topógrafos, na abertura de divisas do parque. Atualmente, sempre 
vou conversar com o diretor, só que o assunto tratado não se refere a palmito. Vou para pegar autorização para a abertura do divisor. Eu só vou falar desse assunto se fosse preciso mesmo, ou no caso de dar uma palestra sobre isso. Esse assunto envolve muita gente.

\subsection{A necessidade de partilhar estratégias de conservação com a população do entorno}

O trabalho publicado por Ferreira (1993) propiciaria um olhar mais apurado na direção do conflito de interesses evidenciado na área estudada. Entender as correlações de forças que se travam em torno dessa questão contribuiria para a construção de projetos educativos, econômicos e culturais mais efetivos e eficientes.

O trabalho dessa autora foi o de analisar mais demoradamente a oposição genérica entre a ação política que reivindicava melhoria nas condições de vida e na qualidade dos sistemas naturais e as ações que congregavam posições de negação ao problema ambiental. Identificou-se quatro modos de ação:

a) O primeiro modo de ação é baseado na organização de categorias definidas a partir da luta de classes e expressa um projeto político socialista.

b) O segundo modo de ação, o ambientalista, foi construído fora do município, onde se encontram suas bases de sustentação.

c) O terceiro modo de ação diz respeito à ação tecnocrática e pode ser definido a partir do discurso técnico articulado a modelos de modernização.

d) O quarto modo de ação, caracteriza-se fortemente pelo sentimento coletivo do 'pertencer', tanto do ponto de vista espacial de pertencer a uma determinada unidade geográfica como cultural, da criação da identidade "dos que ficam" em oposição a um forte sentimento de invasão, provocado pelas características migratórias do município estudado.

Considerando que o parque "Carlos Botelho é uma unidade de conservação de proteção integral, neste trabalho, entrevistou-se uma a 
advogada. Com o nome fictício a advogada afirmou: "a legislação se agrava caso a apreensão de palmiteiros seja feita dentro de uma área protegida. A lei vale para qualquer área, seja esta um parque nacional ou uma propriedade privada".

Os extratores (informantes nesse trabalho) são residentes em Juquiá, mas foram entrevistados na delegacia de São Miguel Arcanjo, pois no período tinham sido presos pela polícia florestal de Itapetininga em flagrante e dentro do parque. A justificativa desses extratores, foi a de que, não tendo emprego, essa ação clandestina passa a ser um "bico" (trabalho temporário), já que não seria possível ficar sem fazer nenhum trabalho.

Segundo o extrator Pedro, "o contratante, um tal de Zé, que nós nem sabe quem é, falou que a tarefa levaria quatro dias". O contratante é o 'atravessador', que pega o palmito no mato (geralmente numa estrada) e leva para uma fabriqueta para o beneficiamento. $O$ 'atravessador' não fica só num município, é o 'cara' que tem dinheiro, que não leva prejuízo e que não vão presos. Quem leva prejuízo somos nós que corta o palmito. Como não podemos fica parado, a gente arrisca mesmo com medo da polícia chegar".

Na delegacia de São Miguel, Tiago (extrator) afirmou: "nós não sabia que o local onde ocorreu a apreensão era parque. Depois que a polícia levaram a gente, que vimos que era parque, por que dentro da viatura deu para ver que tinha até alojamento para os guarda. Se nós soubesse que era parque, nem teria saído de casa, para cair numa cilada. Eu estava muito bem na minha casa, preferia ter ficado passando fome e vivendo de bico".

Perguntando quais seriam os locais onde essa prática ocorre com mais freqüência, Ester respondeu: "a maioria das apreensões ocorre mais dentro do parque. Dentro do parque porque é a área onde a mata está mais preservada. Onde ainda tem palmito e onde essa espécie é menos agredida. Todos os casos que atendi, as apreensões ocorreram dentro do parque". A advogada Ester mencionou: "a maioria dos palmiteiros que são presos em São Miguel procuram por mim". 
Segundo Ester "estes palmiteiros podem até achar que não estão dentro do parque, porque eles são contratados, são pessoas ignorantes. Vão saber onde estão os limites do parque? Os extratores são como 'bóias-frias' fazem o que o contratante pedir. O contratante combina com os extratores e os leva muitas vezes até o local, numa propriedade qualquer, e pede que estes realizem a extração. Se derrepente chega a polícia, os extratores, leigos que são, não sabem dizer nem quem os contratou".

Para Ester: "os extratores ignoram a lei de crimes ambientais, são pessoas sem estudo, sem instrução e nunca vão saber o que é lei e o que é proteção ambiental. Não entendem porque precisam proteger uma coisa, nesse caso, o meio ambiente, se precisam comer. Porque quem entende são as pessoas que realmente estão ganhando, os que vendem o palmito, que são os contratantes. Esses que ganham e que deveriam ser os mais combatidos pela polícia”.

Segundo Ester "a justiça deveria visar mais estes, os contratantes, só que é difícil chegar neles, porque quando a polícia chega no mato, quem está ali? O extrator! E ele está armado! Está ali para extrair o palmito e ainda em duas situações irregulares: uma por estar cometendo um crime ambiental e outra por estar armado. Esse tipo de apreensão ocorre com freqüência e infelizmente sempre estão prendendo palmiteiros na delegacia de São Miguel. Só que essa é uma medida necessária por que essa prática é uma agressão à natureza!"

A proibição do corte de palmito e demais recursos florestais já existe, mas ainda não foi possível a implementação de políticas públicas para que essa ação deixe de ocorrer. Verificou-se que se o parque e a comunidade em geral não se mobilizarem para encontrar soluções de renda para os indivíduos que extraem o palmito clandestinamente, esse problema vai continuar até o último palmito ser extraído.

Barreto Filho (2001), constatou que uma parcela da população (a que vive no local em que se prevê a implementação da UC ou na sua vizinhança 
imediata) vê-se excluída dos eventuais benefícios que a unidade poder gerar, bem como dos fins educativos, recreativos e científicos que visa a cumprir.

Esse autor afirmou que a "integração" das "populações pobres" às UC's tem se dado sem uma definição clara da "meta social a ser atingida", que não a de que as ações humanas não devem contrariar o objetivo da conservação da biodiversidade. A novidade, é a promoção da participação de grupos sociais locais na gestão dos ecossistemas e recursos naturais em que se assenta a sua reprodução sociocultural.

Um trabalho que poderia contribuir nessa direção, está sendo formatado pelo Instituto Brasileiro do Meio Ambiente e dos Recursos Naturais Renováveis (IBAMA, 2002). Essa instituição compreende a educação ambiental, no processo de gestão ambiental.

As ações educativas desse órgão são realizadas com: pescadores, marisqueiras, ribeirinhos, produtores rurais, assentados da reforma agrária, grupo sociais afetados por impactos ambientais e/ou riscos ambientais e tecnológicos, grupos sociais residentes em unidades de conservação e no seu entorno, técnicos e gestores ambientais entre outros segmentos sociais afetados pelas atividades de gestão ambiental de responsabilidade do IBAMA. O ponto de partida desse processo é a análise da realidade socio-ambiental vivida pelos grupos sociais com quem realizam as ações educativas. Para tanto, toma-se como tema gerador do processo de ensino-aprendizagem uma das três situações ambientais possíveis: problema ambiental, conflito ambiental e potencialidade ambiental.

Um outro trabalho, no campo da pesquisa e não exatamente no campo da intervenção, foi realizado por Macedo \& Amaro (1997). A partir de contatos feitos com a equipe responsável pelo Parque Estadual de Itaúnas-ES, os autores selecionaram todas as famílias de agricultores que se localizam na área de influência do mesmo. Esse trabalho realizado sob o enfoque qualitativo, utilizando o método de estudo de caso, visou a coleta de informações sobre essas famílias e baseou-se na técnica de pesquisa qualitativa denominada 
"Focused interview". As conclusões apresentadas na pesquisa, revelaram segundo Macedo \& Amaro (1997), que os sistemas de produção das propriedades rurais localizados nas áreas de entorno do PE de Itaúnas-ES, mantêm uma agricultura de subsistência que, apresenta como base a mão-deobra familiar e produz uma grande diversidade de produtos. A maioria dos agricultores complementam as suas necessidades de madeira, plantas alimentícias e medicinais, caça e pesca através da atividade extrativista clandestina realizada nas áreas do PE de Itaúnas-ES.

Segundo Pimbert \& Pretty (2000), os conservacionistas estão tomando consciência de que uma proteção ambiental efetiva somente é possível se as comunidades estiverem inteiramente envolvidas no planejamento das áreas protegidas e tiverem ganhos diretos do projeto.

Um exemplo é a experiência de manejo sustentável de palmito (Euterpe edulis) junto à população de Batuva, distrito de Guarequeçaba-PR. A região de Batuva está localizada numa área estratégica em relação às rotas de extração ilegal de palmito. Os agricultores declaram não ter como se defender do roubo, pois os palmiteiros podem atacar a qualquer momento (Guimarães et al. 1997)

Os objetivos desse projeto e as atividades relacionadas foram: desenvolver uma mentalidade de sustentabilidade da produção de palmito junto aos agricultores; recompor o banco de plântulas na área de ocorrência natural do palmito; propor um novo sistema de manejo de rendimento sustentado para o palmito; oferecer a oportunidade de exploração do palmito em conformidade com a lei; oferecer uma fonte segura de renda para o agricultor; consorciar banana e palmito; realizar um inventário; manejo sustentável das áreas passíveis de manejo imediato.

Os resultados obtidos, segundo os autores, são positivos. Entre esses, destacam-se: o plantio de mudas consorciado com bananas; recomposição através de semeadura; inventário e classificação das áreas quanto ao potencial de manejo; planos de manejo e conscientização dos agricultores. 


\section{CONCLUSÃO}

Este trabalho, demonstra a busca e compreensão das relações entre conflitos socioambientais e planos-ações educativas, bem como aspectos do manejo relacionados a proposição de soluções para conter a ação clandestina de palmito no interior de unidades de conservação. As diferentes etapas são representadas através de uma descrição do subprograma de educação ambiental do Parque Estadual "Carlos Botelho"- um fazer pedagógico específico e pontual, que não dialoga com outras possibilidades, mostradas na revisão de literatura deste trabalho.

A gestão de conflitos em áreas naturais protegidas, não é do domínio de uma única área de estudo, nem existe, até o momento, um modelo estabelecido que dê conta de auxiliar a compreensão desse fenômeno e formatar ações que levem em consideração o conflito. $O$ modelo de gestão de conflitos em unidades de conservação tem estado focado na gestão dos conflitos internos à unidade, causados pelo uso público - impacto e não para o extrativismo e demais intervenções antrópicas.

No que se refere ao manejo do uso público, o Instituto Florestal adota duas metodologias, ora visando à mudança de comportamento do visitante em relação à natureza, a exemplo da metodologia de mínimo impacto discutida por Barros (2003); ora procurando convencer a população local a colaborar na preservação da unidade de conservação, esta última, alicerçada na educação conservacionista, a exemplo dos trabalhos publicados por Dias et al. (1986), Tabanez (2000) e Simões et al. (2000).

A proposta que mais se aproxima de uma intervenção educativa, na direção de solucionar os conflitos causados pelo extrativismo clandestino, está 
sendo discutida e elaborada no âmbito do Instituto Brasileiro do Meio Ambiente e dos Recursos Naturais Renováveis (IBAMA). À medida que esse órgão se propõe a formatar um modelo de "educação ambiental no processo de gestão', incluindo grupos sociais residentes em unidades de conservação e no seu entorno, técnicos e gestores ambientais, tendo como tema gerador do processo de ensino-aprendizagem o problema ambiental, conflito ambiental e potencialidade ambiental, demonstram reconhecer a dificuldade que é colocar diferentes pessoas, com diferentes interesses e percepções para discutir e elaborar propostas participativamente.

As atividades descritas no subprograma de educação ambiental do parque "Carlos Botelho" não têm nada a ver com o problema do extrativismo clandestino e nem demonstra sinais de que deseja colocar em debate uma educação ambiental nessa direção. No item políticas de gestão do parque, esclareceu-se de que modo são encaminhadas as ações dos programas de administração, uso público, pesquisa e fiscalização, não se verificou a inclusão do tema extrativismo clandestino. Em nenhuma das páginas desse documento, constatou-se a intenção de se perguntar, quem são essas pessoas que estão extraindo o palmito ou como se chega até elas para o estabelecimento de um diálogo.

Verificou-se que as ações dos diferentes programas e projetos não se articulam, e os programas não podem ser considerados um sistema, no sentido exato do termo, porque estes não se retroalimentam. A fiscalização cumpre seu papel de ir a campo para realizar as apreensões de extração, transporte e armazenamento de palmito, enquanto a educação ambiental limita-se à recepção de visitantes no interior do parque. Na relação com a população do entorno, prevalece a idéia questionável de que o ecoturismo será a solução para os desafios de sustentabilidade do parque e da comunidade. A pergunta que se coloca é de que maneira essas pessoas que estão no entorno do parque estarão sendo incorporadas nesse processo? Até o presente, os projeto e programas de educação ambiental, de manejo e outros elaborados pela direção 
do Parque não fizeram parte da vida das pessoas que extraem o palmito, pelo contrário, reforçam a percepção de que o parque é uma coisa que atrapalha e é punitivo.

O aborto de uma possível alternativa para essas pessoas, foi verificado após a não aprovação de um plano de manejo sustentável do palmito, ação que partiu de uma instância de decisões do Instituto Florestal superior a do Parque. Entende-se que o fato do parque ser uma unidade de proteção integral, "que veta qualquer outro tipo de atividade nos parques, a não ser a pesquisa científica e recreação (grifo nosso)" , não impede que esse plano de manejo seja executado no seu entorno.

Por fim, elaborar planos e ações educativas em que as atividades realizadas limitam-se ao fomento do turismo na região do Parque, pode fragilizar os objetivos de proteção da área. Esse foi o motor que gerou a elaboração deste trabalho, definiu a hipótese de análise e permitiu uma aproximação com a rede de extração clandestina. A não consideração desse problema que, segundo a análise parece ser crucial do ponto de vista da preservação da biodiversidade, bem como a não proposição de alternativas para as questões conflituosas, faz com que o subprograma de educação ambiental não fortaleça uma das dimensões que define a sua base epistemológica: a 'resolução de problemas'.

Alicerçada no enfoque conservacionista, a educação ambiental investe em mostrar aos visitantes a biologia do palmito, todavia o parque não favorece o estudo e a apresentação de técnicas que corroborem com a inversão dos níveis de pressão antrópica. Talvez não haja tempo para esperar. Saber que a população do entorno depende desse recurso e não propor alternativas frente a essa problemática, fará com que essa população continue extraindo o palmito, até a extinção total da espécie.

Se o problema está no enfoque da educação ambiental, é preciso que se mude ou, numa vertente mais conciliadora, sejam revisitados os objetivos e as normas que definiram a implantação do Programa de Uso Público do parque. 
Uma contribuição importante, enfatizando a necessidade de tornar o conflito no interior do parque, em um potencializador da educação, é encontrada na obra de Santos (1992). Embora o enfoque desse trabalho não esteja voltado para a educação não-formal, que é o enquadramento mais aproximado, para a educação ambiental em áreas naturais protegidas. $O$ autor não define a quem deve ser aplicado esse tipo de pedagogia, sugere-se que a mesma seja utilizada na formação dos técnicos e monitores que atuam diretamente no Programa de Uso Público do Parque "Carlos Botelho".

Esse autor propõe um modelo de pedagogia alicerçada nos conflitos sociais, nos quais a reorganização do processo de trabalho pedagógico implica em outras regras, outros processos e outras formas de relacionamento pessoal. A necessidade imposta por essa reorganização exige que o conjunto dos trabalhadores do ensino, nesse caso técnicos e monitores ambientais, assuma o controle do processo e do produto de seu próprio trabalho. Isso resultará, segundo o autor, em um novo tipo de aprendizado: aprender a autoconduzir-se.

Como cada modo de produção cria sua própria tecnologia, as relações sociais de tipo novo, construídas na prática ativa e autônoma, geradas a partir das lutas dos trabalhadores, aparecerão como o campo determinante da cristalização de uma nova tecnologia. A característica central desta nova tecnologia será, então, a ligação entre o trabalhador, o meio e o processo de trabalho. As referências dessa proposta não se enquadram nos fundamentos de uma educação liberal, conservadora (grifo nosso) e capitalista. Tratam-se de outras referências; da formação de um coletivo considerando-se que todos têm já um conhecimento sobre sua prática social e sobre os problemas postos por essas formas de atuação.

O autor afirma que não se pretende com essa pedagogia eliminar 0 saber já sistematizado. O objetivo é estabelecer parâmetros que permitam selecionar este saber em função dos objetivos propostos pelo coletivo. A relação do coletivo e de cada um com o saber já sistematizado, expressão de uma prática já realizada, é radicalmente modificada: no lugar de uma 
assimilação passiva, passa-se para a sua destruição enquanto sistema pronto e acabado, provocando uma reordenação dos elementos que o integram, tendo em vista a nova prática em processo de realização. Ë o saber que os integrantes do coletivo já possuem em virtude de sua prática social que deve ser captado, ele deverá ser o início do processo do trabalho pedagógico.

Aprofundar os conceito acerca do que é Educação e os modelos vinculados a esse campo seria uma outra sugestão, bem como as definições do que vem a ser educação formal, não-formal e informal, de modo a estabelecer a função de cada uma. No campo da educação não-formal, Gohn (1999), sem dúvida, estaria na lista das referências bibliográficas. Trabalhos como o de Tassara et al. (2001), Lopes (2002), Carvalho (2001), e Thurler (2001) também comporiam um repertório teórico imprescindível na construção desse novo processo.

Por fim, se as ações de manejo do Programa de Uso Público do Parque, considerarem que a educação ambiental deve ser uma estratégia de enfrentamento de questões conflituosas, como as que envolvem o extrativismo clandestino, a análise contida neste trabalho representará uma contribuição, na compilação de registros que poderão ser reeditados e generalizados para outras unidades de conservação. 


\section{REFERÊNCIAS BIBLIOGRÁFICAS}

ALVES, R. Filosofia da ciência: introdução ao jogo e suas regras. 6. ed. São Paulo: Brasiliense, 1985. 209 p.

ALVES-MAZZOTTI, A.J. O método nas ciências naturais e sociais: pesquisa quantitativa e qualitativa. São Paulo: Pioneira, 1998. 123p.

ANDRADE, W. J. de; GIANNOTI, E. ; SILVA, C. E. F. da Guia das Unidades de Conservação e Produção Florestal no Estado de São Paul IN: CONGRESSO NACIONAL SOBRE ESSÊNCIAS NATIVA, 4., São Paulo, 1992. Anais. São Paulo: Instituto Florestal, 1992. p. 880-885.

AOKI, H. ; ANDRADE, W. J. de Programa de uso público e seus papel na conservação da natureza. IN:CONGRESSO DE UNIDADES DE CONSERVAÇÃO. Curitiba, 1997. Anais. Curitiba: IAP:UNILIVRE: Rede Nacional Pró Unidades de Conservação, 1997. p.370-377.

BARBAS, M. V. Da fazenda velha a São Miguel Arcanjo: a saga do Tenente Urias Emydeo Nogueira de Barros. Indaiatuba: Rumograf, 1998. 152 p.

BARRETO-FILHO, E.T. Da nação ao planeta através da natureza: uma abordagem antropológica da Unidade de Conservação de Proteção Integral na Amazônia Brasileira. São Paulo, 2001. 538p. Tese (Doutorado). Faculdade de Filosofia, Letras e Ciências Humanas, Universidade de São Paulo. 
BARROS, M.I.A. Caracterização da visitação, dos visitantes e avaliação dos impactos ecológicos e recreativos do Planalto do Parque Nacional de Itatiaia. Piracicaba, 2003. 121p. Dissertação (Mestrado) - Escola Superior de Agricultura “Luís de Queiroz", Universidade de São Paulo.

BRASIL SNUC - Sistema Nacional de Unidade de Conservação. www.mma.gov.br/port/sbr/dap/areas...(capturado em 05/08/03),4p.

BRASIL. IBGE - Instituto Brasileiro Geografia e estatísticas IN: www.saomiguelarcanjo.org.br (capturado em 04/08/2003), 2p.

BRITO, M. C. W. de Unidades de Conservação: intenções e resultados. São Paulo: Annablume: FAPESP, 2000. 230 p.

CARVALHO, I.C.M. Educação Ambiental e movimentos sociais: elementos para uma história política do campo ambiental. EDUCAÇÃO: teoria e prática, v.9, p.46-56, 2001.

COSTA, E.C.M. Desenvolvimento cognitivo e atividades lúdicas: transferência de operações de classificação para conservação de massa. São Carlos: 1984. 121p. Dissertação (Mestrado) - Universidade Federal de São Carlos.

DIAS, A.C. ; MOURA NETTO, B.V. ; MARCONDES, M.A.P. Trilha interpretativa do Rio Taquaral. Boletim Técnico do Instituto Florestal. v.40, p.11-32, dez. 1986.

FERRAZ, P.M. Estudo sobre o potencial turístico de São Miguel ArcanjoSP. São Miguel Arcanjo: Prefeitura Municipal de São Miguel Arcanjo, 1999. $630 p$. 
FERRAZ,L.P.M.; VAJABEDIAN, R. Evolução histórica da implantação e consolidação das informações disponíveis sobre o Parque Estadual “Carlos Botelho”. São Paulo: SMA/ CINP/ DRPE / PECB, 1999. 95 p.

FERREIRA, L. da C. Os fantasmas do vale: qualidade ambiental e cidadania. São Paulo: Campinas: Unicamp, 1993. 187 p.

GADOTTI, M. Pedagogia: diálogo e conflito. 3.ed. São Paulo: Cortez- Autores Associados, 1985. 146p.

GARRIDO, M.A.O.; TABANEZ, M.F.; DURIGAN, G. Implantação de área de recreação e de educação ambiental em florestas homogêneas. IN: CONGRESSO FLORESTAL BRASILEIRO, São Paulo, 1982. Anais. São Paulo: Sociedade Brasileira de Silvicultura, 1982. p.64-69.

GHIRALDELLI, P. História da educação. 2. ed. São Paulo: Cortez, 1994. 240p.

GOHN, M.G. Educação não-formal e cultura política: impactos sobre o associativismo do terceiro setor. São Paulo: Cortez, 1999. 120p.

GUIMARÃES, J. L. B.; SANQUETTA, C. R.; ARAÚJO, A J de; FILHO, A F.; SOUZA, G. de; O manejo sustentado de palmito (Euterpe edulis) como alternativa econômica para os pequenos agricultores da APA de Guaraqueçaba: uma proposta. IN:CONGRESSO DE UNIDADES DE CONSERVAÇÃO. Curitiba, 1997. Anais. Curitiba: IAP/UNILIVRE/Rede Nacional Pró Unidades de Conservação, 1997. p.789-802.

INSTITUTO BRASILEIRO DO MEIO AMBIENTE E DOS RECURSOS NATURAIS RENOVÁVEIS Como o IBAMA exerce a educação ambiental. Brasília: Edições IBAMA, 2002. 32p.

LAYRARGUES, P.P. Educação no processo de gestão ambiental. IN: SIMPÓSIO SUL BRASILEIRO DE EDUCAÇÃO AMBIENTAL, 1., Simpósio 
Gaúcho de Educação de Educação Ambiental, Semana Alto Uruguai do Meio Ambiente. Erechim: RS, 2002. Anais. Erechim: EdiFAPES, 2002. p.127-144.

LIBÂNEO, L.C. Didática São Paulo: Cortez, 1994. 261p.

LOPES, R.M.G.P. Concepções pedagógicas e emancipação humana: um estudo crítico. IN: Pimenta, S.G. Saberes pedagógicos e atividade docente. 3. ed São Paulo: Cortez, 2002. p.61-81.

LÜDKE, M.; ANDRÉ, M.E.D.A. Pesquisa em educação: abordagens qualitativas. São Paulo: Pedagógica e Universitária, 1986. 203p.

MACEDO, R.; AMARO, J. P. Análise do sistema de produção e das relações ambientais dos pequenos agricultores residentes nas áreas de entorno do Parque Estadual de Itaúnas - ES. IN: CONGRESSO DE UNIDADES DE CONSERVAÇÃO, 1., Curitiba, 1997. Anais. Curitiba: IAP/UNILIVRE/Rede Nacional Pró Unidades de Conservação, 1997. p.743-752.

MANNIGEL, E.; PARAíSO, L. B.; PARREIRAS, C.P.; Participação como estratégia para resolução de conflitos na gestão de três unidades de conservação ambiental da Mata Atlântica em Minas Gerais, Brasil. IN: CONGRESSO DE UNIDADES DE CONSERVAÇÃO, 3., Fortaleza, 2002. Anais. Fortaleza: Rede Pró Unidades de Conservação/Fundação de Proteção à Natureza/Associação Caatinga, 2002. p.433-442.

MARCONDES, D. A crise de paradigma e o surgimento da modernidade IN: BRANDÃO, Z. (Org.) A crise dos paradigmas e a educação. São Paulo: Cortez, 1994. p.14-29.

MARCONI, M. A. ; LAKATOS, E. M. Técnicas de pesquisa. 4. ed. São Paulo: Atlas, 1999. 90p. 
MAROTI, P. S. ; SANTOS, J.E. Percepção ambiental voltada à uma unidade natural de conservação (Estação Ecológica de Jataí). IN: CONGRESSO BRASILEIRO DE UNIDADES DE CONSERVAÇÃO, Curitiba, 1997. Anais. Curitiba: Instituto Ambiental do Paraná:UNILIVRE/Rede Nacional Pró Unidade de Conservação,1997. p.333-344.

NEVES, M.A.C.M. A crise dos paradigmas em educação na óptica da psicologia. In: BRANDÃO, Z. (Org.) A crise dos paradigmas e a educação. São Paulo: Cortez, 1994. p.48-57.

PIMBERT, M. P.; PRETTY, J. N. Parques, comunidades e profissionais: incluindo "participação" no manejo de áreas protegidas. IN: DIEGUES, A. C. Etnoconservação: novos rumos para a conservação nos trópicos. São Paulo: Hucitec/ NUPAUB/USP, 2000. p.183-224.

SANTOS, J.O. Pedagogia dos conflitos sociais. Campinas: Papirus, 1992. $146 \mathrm{p}$.

SÃO PAULO. Apreensão de palmito. Registro: Polícia Ambiental : 2003. 1p.

SÃO PAULO. Autos de infração . São Paulo: Itapetininga. Polícia Ambiental: 2003. 4 p.

SAVIANI, D. Escola e democracia. 23.ed. São Paulo: Cortez- Autores Associados, 1992. 103 p.

SAVIANI, D. Pedagogia histórico-crítico: primeiras aproximações. 5.ed. Campinas, São Paulo: Autores Associados, 1995. 86p.

SECRETARIA DO MEIO AMBIENTE Programa de educação ambiental do Vale do Ribeira. São Paulo, 1992. 344p.

SECRETARIA DO MEIO AMBIENTE Unidades de conservação ambiental e outros espaços protegidos. IN: Atlas das unidades de conservação 
ambiental do Estado de São Paulo. São Paulo: Secretaria do Meio Ambiente, 2000. p.65.

SILVA, D.A; PFEIFER, R.M. Zoneamento de uso recreativo dos solos do Parque Estadual Carlos Botelho- SP. IN: CONGRESSO NACIONAL SOBRE ESSÊNCIAS NATIVAS, São Paulo, 1992. Anais. São Paulo: Revista do Instituto Florestal,1992. p.117-133.

SIMÕES, E.; WADT, M.F.; CORREARD, J.M. Programa de uso público no Núcleo Picinguaba. IN: CONGRESSO DE UNIDADES DE CONSERVAÇÃO, 3., Fortaleza, 2002. Anais. Fortaleza: Rede Pró Unidades de Conservação/Fundação de Proteção à Natureza/Associação Caatinga, 2002. p.386-396.

TABANEZ, M.F.; PADUA, S.M.; SOUZA, M.G. et al. Avaliação de trilhas interpretativas para educação ambiental. IN: PADUA, S.M., TABANEZ, M.F. (Org). Educação ambiental: caminhos trilhados no Brasil. Brasília: IPÊ, 1997. 283p.

TABANEZ, M. F. Significado para professores de um programa de educação ambiental em unidades de conservação. São Carlos, 2000. 313p. Dissertação (Mestrado) - Universidade Federal de São Carlos.

TABANEZ, M.F.; HERCULIANI, S. Lazer e educação ambiental em florestas do Estado de São Paulo. IN: CONGRESSO FLORESTAL BRASILEIRO. Campos do Jordão, 1990. Anais. Campos do Jordão: Sociedade Brasileira de Engenheiros Florestais. Campos do Jordão, 1990, p.64-68. 
TASSARA, E.T.O.; TASSARA. M.; SORRENTINO, M.; TRAJBER, R. Propostas para a instrumentalização de um educação ambiental transformadora. IN: COSTA, L.B, TRAJBER, R. Avaliando a educação ambiental no Brasil: materiais audiovisuais. São Paulo: Instituto Ecoar para a cidadania, 2001. p.28-46.

THURLER, M.G. Inovar no interior da escola. Porto Alegre: Artmed, 2001. $182 p$.

TOMAZELA, J.M. Ex-palmiteiros produzirão suco para salvar a palmeira. www.estadao.com.br/ciencia/noticias/2002/jan/19/30.htm (capturado em 19/01/2002), $1 p$.

VASAKI, B G.N. ; SILVA, A C. ; DIAS, A . C. ; NETO, B. V. M. Notas sobre o programa de educação ambiental do PE "Carlos Botelho". IN: CONGRESSO DE ESSÊNCIAS NATIVAS, São Paulo, 1992. Anais. São Paulo: Revista do Instituto Florestal, 1992. p.1126-1129.

VASCONCELLOS, J.M.O de Educação ambiental e interpretação: o fortalecimento dos pilares das UC's. IN: CONGRESSO BRASILEIRO DE UNIDADES DE CONSERVAÇÃO, Fortaleza, 2002. Anais. Fortaleza: Rede Pró-Unidades de Conservação/Fundação $O$ Boticário de Proteção à Natureza/ Associação Caatinga, 2002. p.846-847.

YIN, R.K. Case study research: desing and methods. Applied Social Reserarch Methods Series. New York: Sage, 1990. 166p. 
APENDICES 


\section{APENDICE 1.}

\section{Projeto verão 2000: experiência de trabalho coletivo no Programa de Uso Público ${ }^{1}$}

No mês de setembro de 1999, a autora deste trabalho esteve reunida no Parque "Carlos Botelho" para elaboração do planejamento de um projeto visando à recepção e orientação de visitantes. Participaram dessa reunião: seis moradores do bairro Abaitinga (entorno imediato do Parque), duas moradoras do município de São Miguel Arcanjo, duas funcionários do Parque, esta autora e o diretor José Luís Camargo Maia.

As motivações para que aquelas pessoas prestassem serviços no Parque giravam em torno da consciência sobre a importância da área e do desejo de aprimorar seus conhecimentos a respeito sobre o local e da própria atividade de monitorar questões ambientais.

Numa outra reunião, foi definido que o grupo passaria por treinamento, um dia de trabalho que permitisse a preparação de novos monitores e reciclasse os que já atuavam no Parque. Para tanto, foi definido o convite a alguns palestrantes, bem como a escolha de uma coordenação. A administração do Parque forneceria o almoço da equipe, e as funcionárias de apoio à pesquisa, contribuiriam nesse treinamento, coordenando a atividade de "trilha interpretativa".

\section{RECEPÇÃO E TREINAMENTO DE MONITORES VOLUNTÁRIOS}

A recepção dos voluntários foi iniciada com uma dinâmica de apresentação "teia da vida", geralmente utilizada em atividades de capacitação de recursos humanos, pois possibilita uma maior integração entre a pessoas, além de fomentar uma reflexão acerca do conceito de rede.

\footnotetext{
${ }^{1}$ Relatório apresentado ao administrador do parque "Carlos Botelho", como parte de um estágio voluntário realizado no período de setembro de 1999 a novembro de 2000, junto aos programas de educação ambiental e uso público. Essa experiência ocorreu no Projeto Verão 2000, de novembro de 1999 a março de 2000.
} 
Atuando na coordenação desse treinamento, a autora deste trabalho realizou um levantamento das expectativas dos participantes e apresentou os objetivos do treinamento: avaliação e aperfeiçoamento do serviço prestado aos visitantes nas instalações de visitação pública do Parque e revisão e enriquecimento dos aspectos biológicos, geográficos, históricos e sociais do Parque. Os participantes também receberam um material impresso com informações sobre o Parque. Em seguida, foram feitas as exposições orais sobre os seguintes tópicos:

- Caracterização geral do Parque Estadual "Carlos Botelho"

- Histórico e evolução do programa de educação ambiental e uso público

- Educação ambiental em unidades de conservação

- Técnica profissional do monitor

- Gestão e manejo em unidade de conservação

No período da tarde, a partir de um roteiro de observação, foi organizada a visita à trilha do rio Taquaral, que seria interpretada pela bióloga do Parque e funcionárias auxiliares de apoio à pesquisa.

Às margens do rio Taquaral, em diálogo informal, foram trocadas experiência de trabalho prático e apresentados os problemas mais comuns no atendimento a visitantes. Foi considerado necessário orientar os demais, acerca dos horários de trabalho, das responsabilidades, bem como das atividades que poderiam ser realizadas para melhor atender o visitante. Por fim, houve uma breve avaliação na qual foram expostas as necessidades do grupo e comentarários sobre o andamento dos trabalhos do dia.

O início das atividades de recepção, ocorreu uma semana após o treinamento. Foi acertado que todas as segundas-feiras ocorreriam reuniões nas quais seriam apresentados os relatórios dos finais de semana que conteriam as atividades realizadas, no centro de visitantes e demais locais de visitação, as sugestões dos visitantes e monitores, bem como o perfil de visitantes. 
Assim, iniciou-se o Projeto Verão 2000, nome escolhido para as atividades de manejo do uso público, educação e lazer do Parque, atividades que contou com o financiamento da Secretaria de Meio Ambiente (SMA).

\section{RECEPÇÃO DE VISITANTES NAS ÁREAS DE LAZER}

No Posto 8, eram abordados os carros para informar sobre as regras e normas para uma boa visitação nas áreas de lazer. Esse local estava situado na entrada do Parque e no final do trecho asfaltado da estrada SP 139 que corta o Parque de norte a sul. (Figura 1)

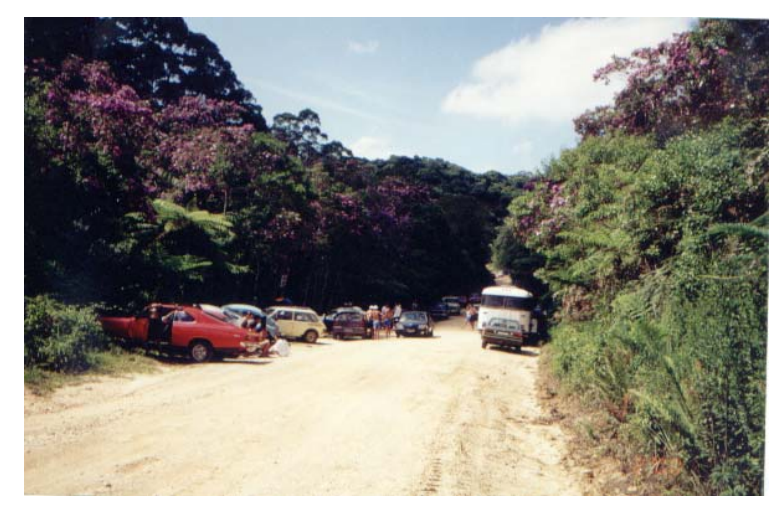

Figura 2- Estrada SP 139: área de lazer

$\mathrm{Na}$ bica, localizada na estrada SP 139, os visitantes eram orientados sobre o problema do lixo na natureza, respondiam ao questionário sobre seu perfil $^{54}$ e recebia ainda sacolas plásticas e folder do Parque. Havia nessa área quiosques e lixeiras à disposição do público.

No museu de zoologia (Figura2), os visitantes apreciavam animais taxidermizados, bem como animais apreendidos, aves da Mata Atlântica, mapas dos vários Parque do Estado de São Paulo, e uma mini-biblioteca.

\footnotetext{
${ }^{54}$ A tabulação da pesquisa sobre o perfil de visitantes do parque "Carlos Botelho" encontra-se no relatório do Projeto Verão 2000.
} 


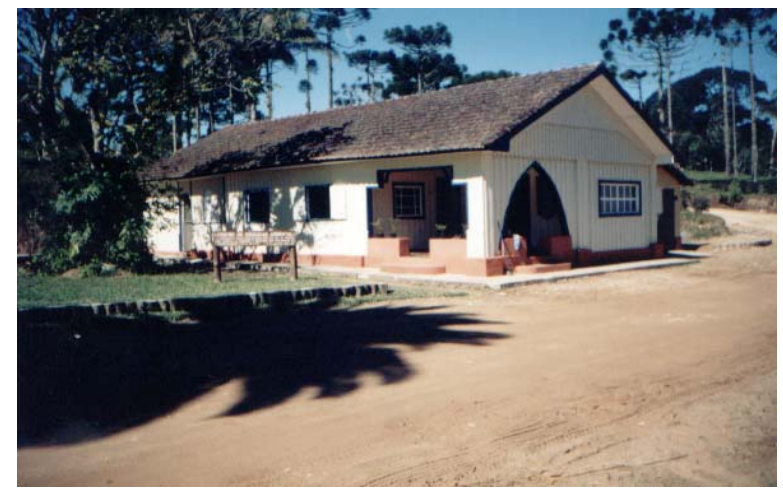

Figura 3- Museu de zoologia do Parque

No centro de visitantes (Figura 3), era feita a apresentação do Parque com o auxílio de vídeo cassete e retroprojetor; na seqüência, eram desenvolvidas atividades educativas ambientais na forma de dinâmicas de grupo.

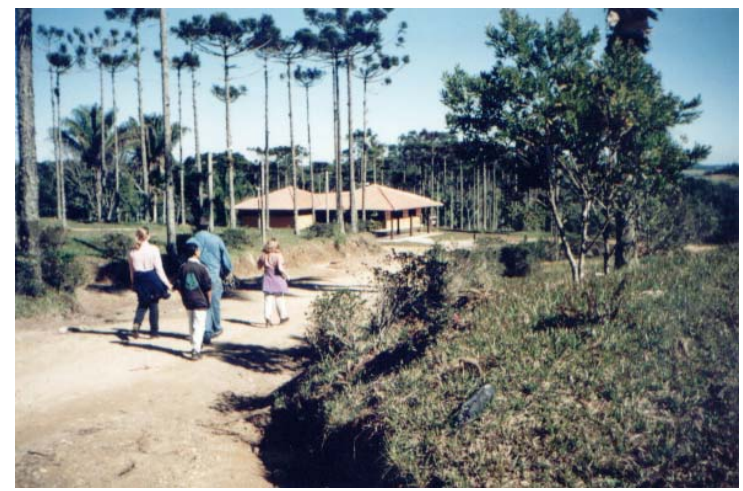

Figura 4 - Centro de Visitantes

Para visitar a trilha da represa (Figura 4), os grupos organizados eram acompanhados, atividade conhecida como excursão monitorada ou trilha interpretativa. 


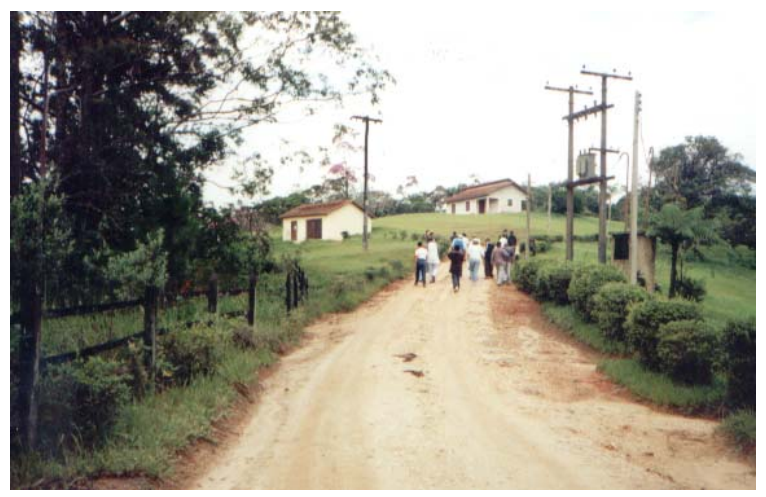

Figura 5 - Caminho até a trilha da represa

Para a verificação da eficiência, bem como do cumprimento dos objetivos propostos no Projeto Verão, elaborou-se um caderno de campo, registros fotográficos das diversas etapas do projeto e registro das entrevistas realizadas junto a equipe do Programa de Uso Público do Parque, técnicas fundamentadas na metodologia de estudo de caso. Os dados coletados, estão sendo utilizados nesta dissertação, mas os resultados específicos do projeto verão, não serão incorporados, visto que o foco desta pesquisa não visa avaliar a eficiência das ações de recepção de visitantes. 


\title{
APÊNDICE 2.
}

\author{
São Miguel Arcanjo \\ Entrevista semi-estruturada realizada em dezembro de 2002, \\ aplicada à rede de extração clandestina de palmito.
}

1- Nome: Mateus (fictício)

2- Idade: 62 anos

3- Profissão: lavrador

4- Civil: casado

5- Filhos: 02

6- Residência: SMA

7- Natural: SMA

8- Vendedor de palmito em SMA

$\underline{\mathrm{O} \text { senhor conhece algum local onde esse assunto é debatido abertamente? }}$ Associação, cooperativa, escola, parque ecológico?

Mateus: NÃO

$\underline{\text { O senhor lembra-se da morte do Marcos Santos da Costa, vigia do parque, que }}$ foi morto por palmiteiros?

Mateus: Não sei há quanto tempo ele morreu, mas eu conhecia, ele era meu amigo. Era filho do Ramirão. Devia ter uns 23 anos. Ele é amigo do meu enteado que trabalha no parque. Para a família dele deve ter sido muito difícil.... eu que era amigo dele senti muito!! Amigo da gente!!

$\underline{O}$ senhor acha que em função dessa prática pode se chegar ao último pé de palmito? (exaustão desse recurso)

Mateus: Acho que a pessoa que corta palmito, se a Polícia Florestal não der em cima deles, eles vão acabar com o palmito. Com o tempo, pode acabar! Pode até ter bastante, mas com o tempo pode acabar. A água está acabando, agora imagine o palmito!! Mesma coisa os animais... eles estão em extinção, se for matando, matando uma hora acaba, acaba tudo, fica sem nada. Por isso tem que ter a Polícia Florestal, para não deixar que seja eliminado o que tem. Se os 
policiais tomarem conta, não vai terminar, agora, se largarem mão de tomar conta, daí eles acabam com tudo.

Mas na fiscalização, sabemos que há um número reduzido de policiais.

Mateus: acho que o governo deveria reforçar a guarda! Acho que é pela via da polícia que se resolve esse assunto, porque eles não respeitam ninguém. Vão cortando tudo que é palmito que vem pela frente. Estão acabando com a natureza, matando os bichos!

Quem são essas pessoas? (palmiteiros)

Mateus: Eu não conheço quem corta, não sei do que eles vivem. Mas eles... você viu... mataram o rapaz que trabalhava no parque! Mas eu acho que se não derem alternativa para eles pararem de cortar o palmito, eles vão acabar com tudo.

$\underline{\text { Que tipo de alternativa seria possível para mudar esse quadro? }}$

Mateus: Se o governo chamasse... uma ordem do governo para chamar eles, reunir eles e dar um serviço para eles.

O senhor conhece alguma associação de palmiteiros? Já ouviu falar?

Mateus: Não, eu acho que não existe! Acha que o 'cara' que vai cortar palmito, ele vai fazer parte de uma associação? Eu conheço fábrica de palmito, que 'envidra' e vende, mas associação não!!

Acha possível propor uma alternativa de renda para que essas pessoas possam estar plantando e colhendo esse recurso? É possível chegar perto deles para um acordo?

Mateus: Acho possível, porque muitos deles não são bandidos, mas se atacarem eles no mato, são capazes de atirar! Essas pessoas têm família, vivem em algum lugar! Porque, veja bem... o palmiteiro faz isso, porque tem que comprar comida, né? Ele não tem emprego. Se ele tem emprego, ele vai trabalhar no emprego dele! Não vai cortar palmito! Para arriscar a levar tiro de polícia lá no mato? Por causa de um 'palmito' ou dois 'palmito'? 


\section{Há uma maneira dessa prática se tornar legal? Há esperanças?}

Mateus: Tem muita gente que eu conheço, que está plantando palmito, por exemplo o Dr. Carmo, o advogado. Na fábrica do Zé Messias, o palmito é trazido do Paraná, e é palmito plantado e com nota fiscal, tudo certinho.

Essas experiências são poucas, comparadas às práticas ilegais?.

Mateus: É pouco! Mas eu acho que o palmito ilegal não está tendo mais por aqui. Se você pede para um "cara” trazer palmito lá do sertão, ele não traz!

Lá no fundo tem bastante!! Lá em Sete Barras, aquele pessoal que vive lá no fundão, eles cortam palmito. Eles cortam o que tem! Mas não deixam amadurecer o palmito, cortam cabritinho (cortado precocemente) !! Acabam com o palmito porque não deixam crescer a palmeira. Fazem isso!!

$\underline{\text { O senhor teve alguma experiência de contemplação da floresta, da beleza do }}$ lugar, dos atrativos do sertão?

Mateus: Eu trabalhei em floresta fazendo medição, abrindo divisor, topografia. Eu achava bonito as cachoeiras, aqueles 'parasitas' que dava na ponta da árvore e descia até o chão.

\section{Como foi o contato com as pessoas do sertão?}

Mateus: São pessoas boas, todos eles são pessoas boas para mim. O que eles têm eles oferecem para a gente, né? Pessoas muito boas!! As pessoas que vivem no sertão e que matam animais, que eu acho uma 'judiação', eles acham normal! Já pensou matar um bicho que está em extinção? Que não vai ter mais!! $\underline{\text { Como o senhor sabe que alguns animais estão em extinção? }}$

Mateus: Eu assisto televisão, vejo filme, Globo Rural, Globo Repórter, a conservação das coisas, né? Estão lutando para que as coisas sobrevivam, né? Por que o senhor acha que não existe uma associação de palmiteiros?

Mateus: (Risos...) cooperativa de palmiteiros? Não sei.... não deve ter não!! (risos) eu acho que não tem!! O palmiteiro vive lá no mato, lá ele pega o palmito dele! Você acha que o palmiteiro vai cortar o palmito e vai vender aqui em São Miguel? 
Se ele for vender vai vender para alguém que vive fora daqui da cidade, longe daqui! O cara já combina com ele, ele entrega para o cara lá não sei aonde, né? Aqui na cidade ele não entrega. E não entrega, porque a polícia prende ele!! A polícia fecha o cerco em cima, não deixa sair!! Então é isso! Se existisse uma cooperativa de palmiteiro, na hora a polícia prendia! Saberia o lugar onde ia ser a reunião dos palmiteiros, né? Ahhhhh! Iria ali e prendia todo mundo!! O senhor acha que não tem conversa? Não há diálogo? Não há alternativas?

Mateus: Acho que não tem!! É um atrás do outro! É um correndo e o outro atrás. Ele foge e a polícia quer pegar. Se estiver com palmito, eles prendem!! Há esperança que isso um dia acabe? Que exista a legalização dessa prática? Mateus: Pode ser.... se as pessoas puderem plantar ele (o palmito). Agora, se liberarem para cortar, todo mundo pode cortar palmito, na reserva (PECB) e em tudo quanto for lugar!? O palmito que tem não dá para um mês, eles cortam tudo!! Eles limpam tudo!! Daí como é que faz? É muito rápido extrair palmito!!! Mas o palmito que tem é muito pouco!! Já tem pouco!! Se liberarem.... acabam com tudo!!

Acha possível extrair o palmito sem acabar com a espécie?

Mateus: O palmito quando está com cacho... (uma vez eu vi uma pesquisa de um engenheiro sobre isso, quando eu estava fazendo demarcação).... O palmito dá cacho, a semente que cai no chão, brota e vira uma muda, vira um coqueirinho! Estavam para liberar que fosse cortado as palmeiras que não tinham cacho, e aqueles que tinha cacho era para deixar, para que virasse muda. Depois eu não sei o que fizeram.

As pessoas que vivem do palmito esperam uma política do governo que facilite suas vidas?

Mateus: Acho que não acreditam nisso!! Não acreditam que o governo vai fazer isso!! Porque são uma gente pobre, né? Descrente de tudo!! Vou dizer uma coisa bem sério: o 'carra' que vai cortar palmito para comprar comida para os filhos dele, é porque ele não conseguiu nada na vida! Porque essa prática é a pior coisa do mundo!! 
Eu sei porque eu estive lá no sertão fazendo picada!! Eu conheci uns palmiteiros, debaixo de chuva, descalço! Mulher descalço, dormindo embaixo de rancho, amanhecia 'ensopa' de molhada! Para tirar uma meia dúzia de palmito para comprar leite para o filho no outro dia!! É a última coisa.... porque não tem emprego!! Em dez minutos o palmiteiro corta a árvore e aquilo nunca mais brota!! Cortou, acabou!! E o comércio de palmito fica em torno da espécie juçara!!

O senhor já participou de alguma atividade de educação para a conservação? O senhor já foi no PECB?

Mateus: Já fui já.... sempre vou lá, conversar com a atual administração e sempre ia conversar com a antiga, tenho maior amizade!! Mas tem o seguinte: não é sobre essas coisas, sobre isso que a gente conversava, não!! Eu ia lá para perguntar sobre abertura de divisor em tal lugar! Pegar autorização deles... essas coisas só!! Mas sobre essas coisa (palmito) nós nunca falamos!! (Silêncio). Acho que falaria mas só se fosse preciso mesmo!! Fazer uma palestra sobre isso... talvez!! Esse assunto 'envolve' muita gente!!

As condições da fiscalização no parque são bastante precárias.

Mateus: Um cara para tomar conta de um parque, para entender, tem que percorrer a área!! Andar junto com a fiscalização, para que ele conheça o que ele está fazendo, mas eles não agüentam!! Precisa ver as condições dos guardas!! Tem guarda por ai que vai vigiar o parque debaixo de chuva, para lá e para cá, escurece no mato!!

A Polícia Florestal também ganha uma miséria e ainda está arriscada a levar um tiro de palmiteiro!! O palmiteiro também está arriscado a levar um tiro por causa de dois litros de leite!! É uma luta, né? Essa prática faz muito tempo.... desde que eu era moleque, há uns cinqüenta anos. É muito tempo e é uma luta!!

Seria possível dialogar com esses palmiteiros?

Mateus: O diálogo com essas pessoas é possível porque eles querem o que há de melhor para eles. Se você falar para um palmiteiro, que você vai ter um emprego, que dá para ele ficar aqui e que dá para ele viver, para não fazer mais 
isso aí, ele não vai mais lá!! Ele vai lá porque não tem o que fazer. Muitas vezes, não sabe nem ler e nem escrever! Não sabe fazer nada!! Só aprendeu a cortar palmito!! O que ele vai fazer? É ou não é?

O senhor já ouviu dizer que em Sete Barras há uma média de 2000 pessoas vivendo da extração de palmito?

Mateus: Imagine!!! Calcule só: se cada uma dessas pessoas cortar uma dúzia de palmito por dia? Faça a conta, Quantos palmitos? Que palmito que agüenta? Palmito demora muito para crescer!! Agora dizem que estão plantando 'pupunha', que brota, se pode cortar que brota, dá outro corte. Que vem da Bolívia, do Peru, não sei de onde. Dizem que é meio amargo, eu nunca comi!! Aqui em São Miguel não têm muito palmiteiro, você acha que tem? O policiamento é mais forte!!

$\underline{\text { O senhor já ouviu falar de suco feito com a polpa de sementes de palmito }}$ juçara"?

Mateus: Não. Sei que os cachos que eu falo para você ele cai no chão e brota. Forma muda embaixo da árvore, os coquinhos (semente) caem no chão, seca na terra, com aquelas folhas em cima (serapilheira), daí brota e sai a muda e cresce o coqueirinho. Eu acho que se cada palmiteiro que cortasse um palmito, plantasse uns cinco, né? Corta um e planta cinco!

A fiscalização não poderia realizar um projeto com esses palmiteiros?

Mateus: Já tentaram!! Já tentaram!! Dizem que tem uma lei de que cada palmiteiro tinha que plantar cem pés de palmito. Eu não sei se plantaram!! Se eu não me engano tem uma lei sobre isso! Quando os palmiteiros vão presos, pagam uns seiscentos reais e saem da cadeia. Quem paga a fiança deles são os 'caras', que compram os palmitos ('atravessador'). Eles vêm lá de fora e tira eles da cadeia. O 'atravessador' que compra o palmito!! Paga uma porcaria para o palmiteiro, para atravessar lá fora!! Têm fábricas de palmito legalizadas, do Zé Messias tem mais de 50 anos!!

E os palmitos embalados no mato? Esses não vão para a fábrica? 
R: Ahh!!! isso aí deve ser um sacrifício medonho!! Embalar palmito no mato!!! Esses dias eu estava vendo uma reportagem, prenderam palmito no mato: prenderam fogão, botijão de gás, estavam cozinhando... Lá em Piedade!! Se bem que compensa, mais do que vender para o 'atravessador', porque o 'atravessador' paga pouco!! Mas essa prática vira só em trabalho para o cara!! Não existe uma maneira para eles se reunirem, trocar idéias, tipo de uma cooperativa. Porque daí pegam os 'caras' né? Agora, se fosse liberado, o cara poderia montar uma cooperativa, né? Porque daí pagaria imposto, passava por uma fiscalização. Antigamente se tirava, cortava, mas com ordem de derrubada, guia florestal e transportava o palmito. la para São Paulo, o caminhão ia cheio de palmito!! Quer dizer caminhões!!! Há uns 30 ou 20 anos!! Acabou essa prática porque foi acabando o palmito!! 


\section{APÊNDICE 3.}

\section{São Miguel Arcanjo}

Entrevista realizada no mês de fevereiro de 2003, junto à rede de extração clandestina de palmito.

Nome: ESTER (fictício)

Escolaridade: $3^{\circ}$ grau completo

Residência: São Miguel Arcanjo

Profissão: advogada

Idade: 48 anos

Filhos: 0

Ocorre com freqüência a apreensão de palmiteiros?

Ester: Sempre a polícia pega! Sempre estão prendendo palmiteiros. Infelizmente é uma medida necessária! Porque, o que eles fazem é uma agressão à natureza!

Os palmiteiros desconhecem a especificidade da lei que protege as unidades de conservação, mas sabem que o corte desse recurso natural os leva para a cadeia. Como a senhora vê essa questão?

Ester: A maioria desses extratores, dessas pessoas que são contratadas para irem para a mata cortar o palmito, são pessoas ignorantes. Ignoram as leis de crimes ambientais. São pessoas sem estudo, sem instrução e nunca vão saber o que é lei e o que é proteção ambiental. Não entendem porque precisam proteger uma coisa, neste caso o meio ambiente, se precisam comer...certo? Porque quem entende... são os que realmente estão ganhando! Aqueles que vendem o palmito!! Aqueles que embalam o palmito! Que são os contratantes!! Esses que ganham e que deveriam de ser os mais combatidos pela polícia! $A$ justiça deveria visar mais estes, os contratantes! Mas é difícil chegar neles, nos contratantes. Porque quando a polícia chega no mato, quem está ali? 0 extrator!! E ele está armado!! Está ali para extrair o palmito! 
E ainda: em duas situações irregulares, pelo fato de estar cometendo um crime ambiental e outro por estar armado! Ele está ilegalmente armado. Porte ilegal de arma!

Ester: O PECB abrange uma área imensa! Extrair palmito numa área protegida, a legislação se agrava! Se eu tenho uma propriedade que têm mata nativa, de jeito nenhum ela é minha!! Eu não posso meter o trator e tirar sem autorização! Sob a pena de estar infringindo a lei, caso eu mexa!! É a preservação ambiental, não importa se ela é um Parque nacional ou uma propriedade privada!

Ao longo dos anos defendendo os extratores que são presos na delegacia, a senhora saberia me dizer, os locais onde mais ocorre esta prática? Se é mais nos limites do PECB ou fora dos limites do Parque?

Ester: Mais dentro do Parque!! Dentro do Parque porque é a área onde a mata está mais preservada! Onde ainda tem palmito! Onde essa espécie foi menos agredida! Todos os casos que eu atendi eram dentro da reserva! Eles podem até achar que não estão dentro, porque eles são contratados, são pessoas ignorantes! Eles lá vão saber onde estão os limites do PECB? Os extratores são usados! Seria importante que a polícia tivesse um serviço de investigação, uma prioridade em cima dos cabeças, dos contratantes! Mas é muito difícil chegar nestes... Tem que saber os locais e derrubar esses locais, fechar esses locais! Daí não vai mais ter palmiteiros, porque não vai ter quem os contrate! Porque os contratantes, são como os 'bóias-frias'. Se você tem uma propriedade, você vai e os contrata para realizar a colheita, o bóia-fria não sabe de nada, ele vai fazer o que você pediu. Você pode inclusive pegar uns 15 homens, levá-los numa propriedade qualquer, que não é sua, dizer para realizarem a colheita. De repente a polícia chega... e a propriedade não é sua... Os bóia-frias leigos não saberão nem dizer quem foi que os contratou!! Deu para entender o exemplo!! 
$\underline{\text { A senhora acha que poderíamos minimizar essa situação com ações educativas }}$ ambientais?

Ester: A educação ambiental deve entrar na escola, desde o primário, mas o que o brasileiro tem tido em matéria de educação? Educação ambiental deveria existir principalmente nessas regiões onde ocorre a extração clandestina. Porque a educação ambiental envolve o ensino como um todo, mas a prioridade deveria ser nessas áreas. Em cidade grande também, porque se um paulistano, por exemplo, comprar um sítio... eles precisam saber que precisam usufruir sem agredir!

Acho que a sua pesquisa está abordando um caso, que é a extração clandestina. Mas não é só o palmito que vem sendo agredido! A agressão é contra a madeira, árvores maravilhosas encontradas no Brasil que são também clandestinamente extraídas!! Tanta madeira ilegal extraída na Amazônia! Essa extração ocorre aqui no município também, mas em menor escala!

A senhora sabia que já foram criadas unidades de conservação através de Decretos de Lei, sem uma infra-estrutura definida e muitas vezes sem o diálogo com a população residente no local?

Ester: Está faltando que o cidadão aprenda isso! A falta de pessoal para poder controlar tudo isso é um problema daqui do PECB, é um problema da Amazônia, é um problema federal. O governo não tem como manter o pessoal, os salários do pessoal da fiscalização. Como que o governo pode nos ajudar? Elaborando um projeto de Lei, onde seja obrigatório na escola a educação ambiental. Com um professor específico para ensinar essa matéria! Do mesmo jeito que tem um professor de Matemática e outro de Geografia.

Os professores de São Miguel Arcanjo visitam o Parque todos os anos, com os alunos das escolas!!

Ester: mas acontece que eles (os professores) não estudaram para isso! Eles vão ver o que eu vejo! Eu estudei Ciências do Direito- o quê eu sei sobre a matéria que você estudou? Você é uma especialista em educação ambiental! 
Sou contra essa idéia de achar que o professor de Matemática vai dar aula de EA!! Acho errônea, enquanto isso os brasileiros ficarão sem EA! Deve ser específica... onde o aluno possa apreender o que é a destruição das florestas e da fauna para a sobrevivência do homem! O que é educação? É incutir na cabeça das crianças os valores de preservação!! 